\title{
Domestic energy mapping to enable area-based whole house retrofits
} RAJAT GUPTA AND MATT GREGG LOW CARBON BUILDING RESEARCH GROUP, OXFORD INSTITUTE FOR SUSTAINABLE DEVELOPMENT, SCHOOL OF ARCHITECTURE, OXFORD BROOKES UNIVERSITY, OXFORD, UK rgupta@brookes.ac.uk

\begin{abstract}
A long-standing challenge for area-based mass retrofits has been the ability to rapidly and accurately target appropriate dwellings for energy improvements. This paper demonstrates the application of a data-driven localised Geographical Information System (GIS)-based domestic energy mapping approach to create house-by-house baseline energy models and predict the potential for whole house energy retrofits in a case study of 431 dwellings in Oxford (UK). Topdown spatial datasets on energy, housing, socioeconomics and fuel poverty are combined with bottom-up energy modelling underpinned by actual dwelling details gathered through questionnaire surveys by the local community group. Multiple routes of identifying suitable dwellings were tested such as grouping dwellings with high energy use, those with high levels of fuel poverty and by common dwelling characteristics. About 300 dwellings were found to be suitable for a whole house retrofit package, equating to $89-94 \%$ mean energy reduction over baseline. While the most common dwelling typology, 1930s semi-detached had high retrofit need, it fell in area with low annual household income. The second most common dwelling typology, 1930s terrace, was dominant in areas with median level of household income. Funding programmes will need to be customised for different household segments to increase the take-up of energy retrofits.
\end{abstract}

\section{Abbreviations}

BREDEM - The Building Research Establishment Domestic Energy Model

COP - Coefficient of Performance

DECoRuM - Domestic Energy, Carbon counting and carbon Reduction Model

ECO / ECO3 - Energy Company Obligation / ECO3 - third phase of the ECO scheme

EER - Energy Efficiency Rating of EPC

EPC - Energy Performance Certificate

FiT - Feed-in Tariff

LCCG - Low Carbon Community Group

LSOA - Lower Layer Super Output Area

MSOA - Middle Layer Super Output Area

PV - Photovoltaic

SAP - Standard Assessment Procedure

$\mathrm{RH}$ - Rose Hill (case study)

$\mathrm{RHI}$ - Renewable Heat Incentive

\section{Introduction}

Decarbonisation of the domestic building sector is essential for achieving UK's legal commitment to net zero emissions by 2050 (BEIS and Skidmore, 2019). To date UK has outperformed previous target emissions reductions (BEIS, 2018). However, the housing sector in the UK is one of the 
oldest and least energy efficient in Europe and has been lagging to meet its share of emission reductions. According to the CCC (2019) it is estimated that retrofitting the UK's entire housing stock by 2050 would need to be done at the rate of 1.6 homes every minute. This rate assumes that all possible improvements are done in one go, rather than the piecemeal approach currently adopted (Early, 2020).

Policies to improve the energy efficiency of existing housing (Green Deal) have so far delivered only limited improvements. The $£ 640$ million per year Energy Company Obligation (ECO) programme is the largest energy efficiency scheme in Great Britain. Through ECO, energy companies in the UK are required to invest in improving the existing housing stock funded through a payment incorporated into energy consumers' fuel bills. Currently ECO is in phase 3 running from 2018 to 2022 . About $30 \%$ of the ECO energy efficiency measures are projected to be installed in fuel poor homes (IET, 2018). Moreover ECO mostly results in low-hanging fruit such as loft and cavity insulation, and the retrofit work generally focuses on one house at a time, often one measure at a time (Friedler and Kumar, 2019; Early, 2020). At this pace, current policy will not be able to deliver the required rate of retrofit to meet carbon targets (IET, 2018; Energy Systems Catapult, 2019). Furthermore, the current approach may lead to the lock-in effect ${ }^{1}$ (Ürge-Vorsatz and Herrero, 2012) as past retrofit customers may be more difficult to convince for a further set of more ambitious retrofit measures.

The UK Government also has a statutory, albeit vague, target to raise as many fuel poor homes as is 'reasonably practicable' to Energy Performance Certificate (EPC) Band C by 2030, with milestones of Band E by 2020 and Band D by 2025. Broadly, the goal is to have as many homes as possible improved to EPC Band C by 2035 (BEIS, 2018). However, according to Institute for Public Policy Research (IPPR) (Emden et al., 2018), the government's main policy aimed at achieving this target, the ECO, is insufficient and at the current rate of progress IPPR analysis shows that elevating all fuel-poor households to EPC band C would not be achieved until 2091 at the earliest.

Whole house retrofit is a proposed solution to meet the greater magnitude of change required whilst avoiding the lock-in risk. Whole house retrofit, as assessed though one meta-study (Cluett and Amann, 2014), is described as:

- Significant improvements to the building shell through insulation improvement of most if not all surfaces of the thermal envelope, with attention to air sealing.

- Upgrades to heating, cooling, and hot water systems, including the improvement to or replacement of the existing distribution systems for heating, cooling, and/or hot water.

Though not specifically defined by a target in the UK, the intent of whole house retrofits have ranged from $60 \%$ to $80 \%$ reduction in $\mathrm{CO}_{2} \mathrm{e}$ emissions (Gupta et al., 2015; NEF, 2020). However, as shown in the UK's Retrofit for the Future Programme, dwellings for which pre- and post-retrofit emissions data were available, an average reduction of $54 \%$ was achieved (Gupta et al., 2015). Irrespective of the magnitude of carbon emission reduction achieved, the focus of such programmes has been on individual house demonstrators spread throughout the country.

Given the rate and scale of retrofit required, mass-retrofit defined as retrofit of multiple dwellings at a community or city scale will be necessary to meet demanding carbon targets. The Committee on Climate Change (2019) has also called for mass retrofit to be a UK infrastructure priority. Due to the relative homogeneity of urban/suburban neighbourhoods/streets in many areas of the UK (Gupta and Gregg, 2013), formulation of customisable retrofit packages on a mass scale is possible. Mass-retrofit of many buildings with similar, almost identical characteristics can reduce cost through economy of scale and bulk material buying (Ariffin et al., 2016; Cousins et al., 2010;

\footnotetext{
${ }^{1}$ Or lock-in risk defined as the unrealised energy and carbon saving potentials that result of the installation of below state-of-the-art energy efficiency technologies in buildings.
} 
Friedler and Kumar, 2019). Ideally lower costs should in turn motivate homeowners (Cityfied Project, 2015).

Energy System Catapult in the UK has recommended combining the whole house retrofit approach with place-based (also referred to as area-based) solutions since such programmes can play a key role in building supply chains and early deployment of integrated solutions, as well as driving postCOVID19 economic stimulus, skills development and job creation (Energy Systems Catapult, 2020). However, area-based mass retrofit schemes need to be better targeted to result in a higher uptake. The UK government's net-zero emissions target also requires city authorities to identify areas in need of energy retrofits based on dwelling specific criteria. A long-standing challenge for area-based mass energy retrofits has been the ability to rapidly and accurately target appropriate areas. Urban energy models can help to identify local areas for energy action; however, use of such models to spatially identify individual dwellings for whole house retrofits has been limited.

To address this challenge, this paper demonstrates the application of a Geographical Information System (GIS)-based domestic energy mapping approach to model, map and manage domestic energy use and carbon emissions at a dwelling and neighbourhood level for 431 dwellings in Oxford (Oxfordshire, UK). Drawing on top-down and bottom-up datasets on local housing, socioeconomics, rate of fuel poverty and energy, combined with dwelling-level data collection by the local low carbon community group, suitable dwellings in the neighbourhood are geo-targeted for deployment of mass whole house retrofit based on energy consumption, fuel poverty and common dwelling characteristics.

\section{Review of domestic energy mapping approaches}

As the need to retrofit the existing housing stock is a concern in many countries, there is a growing body of research on using Geographic Information System (GIS) to geo-target energy programmes at district and city scale, using bottom-up (Calderón et al., 2015) and top-down (Gupta and Gregg, 2017) approaches. Spatial mapping enables storage and layering of data so many different attributes (e.g. characteristics of buildings and landforms) can be shown on one map allowing the analysis of patterns and relationships. This can aid urban energy planning through estimation of the environmental and financial implications of different energy reduction approaches (Gupta, 2009; Mhalas et al., 2012).

Moghadam et al. (2016) have used top-down and bottom-up data, period of construction, built form and other census data including occupant count, to project the energy consumption at a district and city scale in Settimo Torinese, Italy. Similarly, Caputo and Pasetti (2017) combined EPC data with other statistical data and regional data to derive the energy consumption for GIS presentation in a medium sized municipality in the Lombardy region of Italy. Droutsa et al. (2016) also mapped Energy Performance Certificate (EPC) datasets throughout Greece. Their findings showed that $34 \%$ of the residential buildings were rated at the lowest energy class, while only $3 \%$ class-B or higher. Quan et al. (2015) used basic building information, mutual shading, microclimate and occupant behaviour in an energy performance calculator engine to visualise energy consumption in New York, USA. In Massachusetts, USA, utility program administrators used GIS to spatially evaluate energy efficiency program penetration throughout the state. The study showed how GIS can help evaluate where the energy efficiency program has been effective and to improve targeting of the program to future customers (Crowley and GL, 2014). This demonstrates the effectiveness of using GIS to locate and identify areas of focus. Another top-down method estimated consumption for a city by downscaling via a multiple linear regression model, large datasets including housing characteristics and aggregated energy use (Mastrucci et al., 2014a).

As examples of more area-based approaches, in both Italy (Delmastro et al., 2016) and the UK (CSE, 2017) thermal models based on actual consumption data have been used to evaluate space heating energy demand in order to optimise planning for district heat networks. de Santoli et al. (2018) comparatively mapped energy consumption and renewable energy systems (RES) to identify the additional RES to provide energy independence to the Lazio region of Italy. The 
findings provided an overall assessment of the renewable energy system potential for the region, where to pinpoint action, and the formulation of proposals aimed at increasing the share of electricity production from renewables. Similarly, (Groppi et al., 2018) analysed the energy demand with PV and solar thermal renewables potential on a house-by-house basis for two areas in Ladispoli, Italy. Such GIS linked models are becoming invaluable to urban energy planners in local authorities to assist in their development of policies aimed at reducing energy consumption and $\mathrm{CO}_{2} \mathrm{e}$ emissions (Gadsden et al., 2003; Gaspari et al., 2020). One example in the UK is the People's Power Station that spatially locates renewables and energy efficiency projects undertaken in Oxfordshire (Low Carbon Hub, 2020).

Table 1 lists selected studies which use spatial mapping to target local areas for energy retrofits. The table outlines the location, retrofit target, method used, measures modelled and number of dwellings assessed.

Table 1. Studies using spatial mapping to assess potential for domestic energy retrofits

\begin{tabular}{|c|c|c|c|c|c|}
\hline Study & Location & Target & Method & Measures modelled & $\begin{array}{l}\text { Total } \\
\text { dwellings }\end{array}$ \\
\hline $\begin{array}{l}\text { Galante } \\
\text { and Pasetti } \\
(2012)\end{array}$ & $\begin{array}{l}\text { Five } \\
\text { municipalities } \\
\text { in Milan, Italy }\end{array}$ & $\begin{array}{l}20 \% \text { reduction } \\
\text { by } 2020\end{array}$ & $\begin{array}{l}\text { Extrapolation } \\
\text { from detailed } \\
\text { category and } \\
\text { age group } \\
\text { assessment } \\
\text { per } \\
\text { municipality }\end{array}$ & $\begin{array}{l}\text { Double glazing, wall } \\
\text { insulation, roof } \\
\text { insulation }\end{array}$ & $\begin{array}{l}>33,000 \\
\text { (est.) }\end{array}$ \\
\hline $\begin{array}{l}\text { Centre for } \\
\text { Sustainable } \\
\text { Energy } \\
(2013)\end{array}$ & $\begin{array}{l}\text { Housing stock } \\
\text { in the South } \\
\text { West, } \\
\text { Midlands and } \\
\text { Wales, UK }\end{array}$ & Not specified & $\begin{array}{l}\text { Dwelling and } \\
\text { Local Authority } \\
\text { Area scale, } \\
\text { bottom up } \\
\text { modelling }\end{array}$ & $\begin{array}{l}\text { Air and ground } \\
\text { source heat pumps, } \\
\text { Direct electric } \\
\text { heating, Electric } \\
\text { vehicles, Solar PV }\end{array}$ & $\begin{array}{l}\text { Not } \\
\text { specified }\end{array}$ \\
\hline $\begin{array}{l}\text { Lannon et } \\
\text { al. (2013) }\end{array}$ & $\begin{array}{l}\text { Neath Port } \\
\text { Talbot, Wales }\end{array}$ & $\begin{array}{l}\text { Near zero by } \\
2050(80 \% \\
\text { reduction })\end{array}$ & $\begin{array}{l}\text { Extrapolation } \\
\text { of SAP model } \\
\text { by form and } \\
\text { age group }\end{array}$ & $\begin{array}{l}\text { Wall insulation, loft } \\
\text { insulation, new } \\
\text { boilers, double } \\
\text { glazing and low } \\
\text { energy lighting, PV, } \\
\text { thermostat reduction }\end{array}$ & $\sim 55,000$ \\
\hline $\begin{array}{l}\text { (Mastrucci } \\
\text { et al., } \\
\text { 2014b) }\end{array}$ & $\begin{array}{l}\text { Rotterdam, } \\
\text { Netherlands }\end{array}$ & Not specified & $\begin{array}{l}\text { Extrapolation } \\
\text { of thermal } \\
\text { models by form } \\
\text { and age group }\end{array}$ & $\begin{array}{l}\text { External wall, roof } \\
\text { and ground floor } \\
\text { insulation, low-E } \\
\text { glazing, high } \\
\text { efficiency boilers. }\end{array}$ & $\sim 300,000$ \\
\hline $\begin{array}{l}\text { Mastrucci et } \\
\text { al. (2015) }\end{array}$ & $\begin{array}{l}\text { Esch-sur- } \\
\text { Alzette, } \\
\text { Luxembourg }\end{array}$ & $\begin{array}{l}\text { EN 15643- } \\
2: 2011 \text { and EN } \\
\text { 15978:2011 } \\
\text { standards }\end{array}$ & $\begin{array}{l}\text { Extrapolation } \\
\text { from form and } \\
\text { age group }\end{array}$ & $\begin{array}{l}\text { Wall, floor and roof } \\
\text { insulation }\end{array}$ & $\sim 13,000$ \\
\hline $\begin{array}{l}\text { Wyrwa and } \\
\text { Chen } \\
(2017)\end{array}$ & $\begin{array}{l}\text { Krakow, } \\
\text { Poland }\end{array}$ & Not specified & $\begin{array}{l}\text { Bottom-up - } \\
\text { georeferenced } \\
\text { datasets }\end{array}$ & District heating & $\begin{array}{l}\text { Not } \\
\text { specified } \\
\text { (entire } \\
\text { city) }\end{array}$ \\
\hline $\begin{array}{l}\text { Giffinger et } \\
\text { al. (2014); } \\
\text { Pont et al. } \\
\text { (2019) }\end{array}$ & $\begin{array}{l}2 \text { quarters in } \\
\text { the City of } \\
\text { Linz, Austria }\end{array}$ & $\begin{array}{l}\text { EU's 20-20-20 } \\
\text { targets; Upper } \\
\text { Austria targets: } \\
39 \% \text { heat } \\
\text { reduction and }\end{array}$ & $\begin{array}{l}\text { Survey, bottom } \\
\text { up, EPC, solar } \\
\text { potential } \\
\text { mapping }\end{array}$ & $\begin{array}{l}\text { Increasing energy } \\
\text { efficiency through } \\
\text { thermal } \\
\text { Refurbishment (e.g. } \\
\text { insulation, glazing), }\end{array}$ & $\begin{array}{l}\text { Not } \\
\text { specified } \\
\text { (two } \\
\text { districts) }\end{array}$ \\
\hline
\end{tabular}




\begin{tabular}{|c|c|c|c|c|c|}
\hline & & $\begin{array}{l}65 \% \text { reduction } \\
\text { in } \mathrm{CO}_{2}\end{array}$ & & $\begin{array}{l}\text { new heating system, } \\
\text { heating control } \\
\text { renewable energy }\end{array}$ & \\
\hline $\begin{array}{l}\text { Gupta and } \\
\text { Gregg } \\
(2018)\end{array}$ & $\begin{array}{l}6 \text { communities } \\
\text { from Wales, } \\
\text { North and } \\
\text { South } \\
\text { England }\end{array}$ & $\begin{array}{l}80 \% \text { from } 1990 \\
\text { levels by } 2050\end{array}$ & $\begin{array}{l}\text { Dwelling and } \\
\text { neighbourhood } \\
\text { scale, bottom } \\
\text { up modelling }\end{array}$ & $\begin{array}{l}\text { Wall, loft, floor, pipe, } \\
\text { and water tank } \\
\text { insulation; double } \\
\text { glazing; high eff. } \\
\text { Boiler, heating } \\
\text { controls; energy eff. } \\
\text { Lighting; PV, solar } \\
\text { hot water }\end{array}$ & 1,659 \\
\hline $\begin{array}{l}\text { Pedro et al. } \\
\text { (2018) }\end{array}$ & Lisbon & $\begin{array}{l}\text { LEED - } \\
\text { Neighbourhood } \\
\text { Development } \\
\text { (ND) }\end{array}$ & $\begin{array}{l}\text { Top-down city } \\
\text { scale }\end{array}$ & $\begin{array}{l}\text { Pre-requisites of } \\
\text { LEED - ND: Smart } \\
\text { location \& linkage, } \\
\text { Neighbourhood } \\
\text { Pattern; Green } \\
\text { infrastructure and } \\
\text { energy performance; }\end{array}$ & $\begin{array}{l}\text { Not } \\
\text { specified }\end{array}$ \\
\hline
\end{tabular}

Most of the studies identified in Table 1 use statistical data and combine both top-down and bottom-up data to visualise energy consumption and potential for improvement. Utilisation of dwelling built form and age group is the dominant way of extracting information about the energy performance of dwellings. Only two studies have examined the potential for deep energy reductions. (Lannon et al., 2013) explored various pathways to $80 \%$ reduction, and found that out of 625 retrofit scenarios only about $1.6 \%$ achieved $80 \%$ reduction. One such scenario modelled ambitious decarbonisation of the grid, $80 \%$ and $40 \%$ uptake of small and large PV systems respectively, and expectations in behaviour change. Predicting the potential for whole house retrofits on a house-by-house level appears to be lacking.

This study combined top-down and bottom-up datasets to identify areas of high energy consumption and create house-by-house maps to visualise energy consumption and assess the potential for whole-house retrofits. A key innovation was the active engagement with a local community energy group to gather dwelling-level data for the study area to underpin the domestic energy models. Retrofit measures were aggregated by dwelling type to enable bulk installations and drive down installation costs.

\section{Methodology}

The methodology for the study comprised of three principal steps for the selected case study area:

1. Top-down assessment of the local area

2. Engagement with the local community group to increase interest and gather bottom-up data about dwellings

3. Neighbourhood modelling to assess energy consumption and retrofit potential

\subsection{Top down assessment}

The case study area in the city of Oxford was chosen by drilling down from top-down publicly available data to find the most vulnerable and/or high energy consuming areas in which active Low Carbon Community Group (LCCG) was present. These datasets included the UK Government's sub-national energy (BEIS, 2017b) and fuel poverty (BEIS, 2017a) data at lower layer super output area (LSOA) comprising approximately 400-800 dwellings, along with EPC data, provided through open access by the Ministry of Housing, communities and Local Government (MHCLG, 2017b). A key aspect in the selection of the Rose Hill $(\mathrm{RH})$ case study area (Figure 1) in South of Oxford was the strong presence of an active LCCG. 
The RH community has a strong low carbon community group (LCCG) presence that has led awareness raising campaigns regarding heat loss through thermography and held talks featuring insulation experts offering free advice to residents in 2018-2019. The authors have also done previous work with the community involving solar photovoltaics and battery storage (Bruce-Konuah and Gupta, 2017). Beginning in 2019 the authors collaborated with the LCCG to define an appropriate area to carbon map. A boundary was defined around an area comprising 431 dwellings with the intent to cover a wide range of dwelling types, ages and tenure.

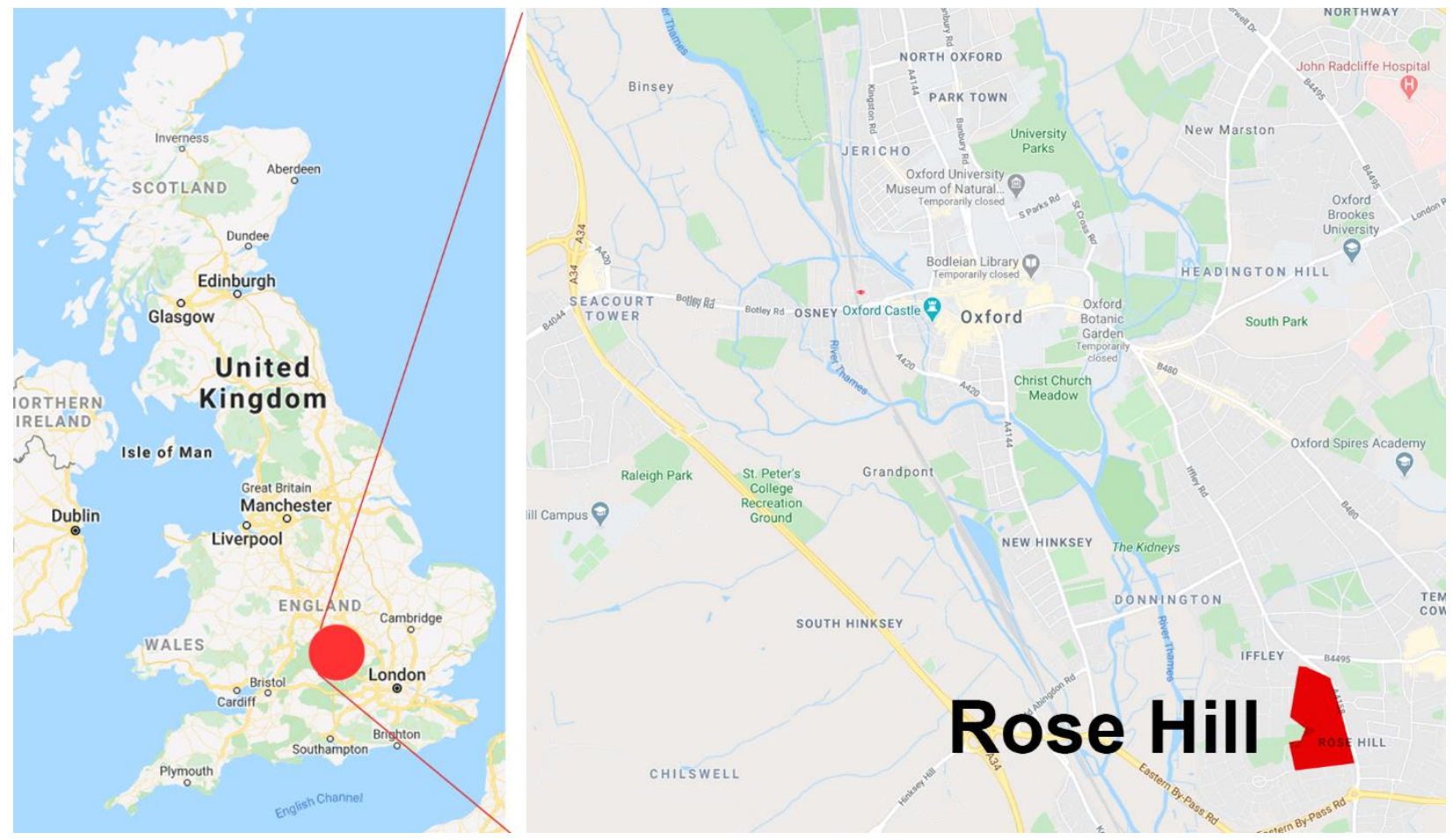

Figure 1. Rose Hill case study area in Oxford (background image: Google maps)

\subsection{Engagement with the local community group}

The objective of engagement with the local community was to increase interest in dwelling energy retrofits by gathering data about the dwelling characteristics, heating system and unregulated energy use - data which could not be gathered from an external inspection of the dwellings. The LCCG participated in the study to use the modelling results to develop an offering for low carbon retrofits to make the estate net-zero carbon. Meeting with the community group representative provided the insight that the community group was interested in providing retrofit options for the 1930s dwellings in the area as a first step. Based on this, an area to be mapped was agreed upon with the LCCG. The authors then designed an online questionnaire for the households in the area to gather real data about dwelling characteristics that could not be gathered from external observation.

Following a few pilot runs, the LCCG then sent the questionnaire out to their email list and dropped leaflets off to the houses located in the immediate area to be mapped. The questionnaire was created using Google Forms open for a little over two months from the end of November 2018 and was incentivised with a $£ 50$ prize to one random winner. The questionnaire was designed to gather data on occupancy, construction details, energy use for lighting, cooking and appliances, details on renewables and eligibility for ECO funding. Table 2 lists these variables.

Table 2. Variables for which data were gathered in the home energy questionnaire 


\begin{tabular}{|l|l|}
\hline Subject & Variables \\
\hline Household & Number of occupants \\
\hline Dwelling general & Estimated age of dwelling, number of floors, enclosed porch \\
\hline Dwelling fabric & $\begin{array}{l}\text { Loft or wall insulation presence, loft insulation thickness, floor structure } \\
\text { type, window frame type, window glazing, draughtproofing, roof-lights, } \\
\text { loft extension, open fireplaces, ventilation type }\end{array}$ \\
\hline $\begin{array}{l}\text { Heating and hot } \\
\text { water }\end{array}$ & $\begin{array}{l}\text { Heating fuel, heating system / boiler type, hot water pipework } \\
\text { insulation, cylinder insulation thickness, additional heating sources }\end{array}$ \\
\hline Unregulated energy & Proportion of low energy light bulbs, fuel used for cooking \\
\hline Renewables & $\begin{array}{l}\text { Thermostat setpoint } \\
\text { supplier name }\end{array}$ \\
\hline Socio-economic & $\begin{array}{l}\text { Photovoltaics, Solar thermal system, Feed-in Tariff (FiT), Renewable } \\
\text { Heat Incentive (RHI) }\end{array}$ \\
\hline $\begin{array}{l}\text { Does the cost of fuel influence how much you heat your home?; Is 10\% } \\
\text { or more of your annual net income used to pay your energy bills?; Do } \\
\text { you qualify for benefits? }\end{array}$ \\
\hline
\end{tabular}

\subsection{DECoRuM energy modelling}

A pre-exiting GIS-based carbon-mapping model called DECoRuM (Domestic Energy, Carbon counting and carbon Reduction Model) (Gupta, 2009; Gupta and Gregg, 2018) was used in the study to visualise energy consumption and retrofit potential in the area. To assess changes in energy use at the household level, heat loss from fabric and ventilation, energy use from heating, domestic hot water and electricity use calculations are performed by BREDEM-12 (Building Research Establishment's Domestic Energy Model). BREDEM is a methodology for calculation of the energy use of dwellings based on characteristics; it is suitable for stock modelling. It shares some features with the SAP (Standard Assessment Procedure) methodology, but allows users to adjust inputs which are fixed in SAP (BRE, 2015). For context, there are more inputs than that required for EPCs; however, the data are collected based on dwelling statistics, external observations, and ideally where possible, occupant-completed home energy surveys. Though not as robust as dynamic thermal simulation, the strength of DECoRuM is in the ability to rapidly process results for many dwellings and present them on an urban scale. The tool is useful for communicating energy related concepts and identifying potential areas for concern and further investigation, including simulation, house assessment and monitoring.

The original BREDEM-12 model requires input data for almost 95 parameters to predict dwelling energy consumption (Anderson et al., 2002). Though all these data are measurable, it is difficult to obtain in practice, owing to the high cost of detailed on-site surveys. This poses considerable problems for energy modelling on an urban scale. In response to this problem, DECoRuM's data reduction technique classifies the 95 input data parameters required by BREDEM-12 into four categories:

1. Data common for all dwellings (50 input parameters, e.g. degree day region, height above sea level, site wind speed) sourced from BREDEM-12 reference tables (Anderson et al., 2002; BRE, 2015), English House Condition Survey.

2. Data derived from built form of the dwellings (five input parameters, e.g. zone areas, occupancy, window area) sourced from standard dwelling configurations reports. 
3. Data derived from age of the dwelling (18 input parameters, e.g. heating system, controls, U-values) sourced from BREDEM-12 reference tables, English House Condition Survey.

4. Data collected for individual dwellings (22 input parameters, e.g. ground floor area) Characteristics that are collected and entered into the model include: built form, floor area, dwellings age, exposed wall area, orientation, wall, roof and window type and insulation where available, renewables, etc.

Some examples of primary data and their sources are listed in Table 3.

Table 3 Data sources for DECoRuM carbon mapping approach

\begin{tabular}{|c|c|}
\hline Data & Source \\
\hline $\begin{array}{l}\text { Dwelling age, form, location, material } \\
\text { characteristics, renewables }\end{array}$ & $\begin{array}{l}\text { Historic and current maps (e.g. historic digimap (Edina, } \\
\text { 2017), Ordnance Survey, Google maps) }\end{array}$ \\
\hline $\begin{array}{l}\text { Dwelling form, window sizes and type, } \\
\text { details not seen in Google street view or } \\
\text { aerial (e.g. photovoltaics) }\end{array}$ & On-site assessment \\
\hline $\begin{array}{l}\mathrm{CO}_{2} \mathrm{e} \text { emissions factors / Fuel cost per } \\
\mathrm{kWh} \text { (common to all dwellings) }\end{array}$ & DBEIS (BEIS, 2016) / uSwitch (uSwitch, 2020) \\
\hline $\begin{array}{l}\text { Material and system (e.g. heating) details } \\
\text { as specific to dwelling age and type }\end{array}$ & $\begin{array}{l}\text { Literature describing home characteristics based on age } \\
\text { and dwelling type (e.g. English House Condition Survey } \\
\text { (Davidson, 1995), BREDEM-12 reference tables (BRE, } \\
\text { 2015),UK Housing Energy Fact File (Palmer and Cooper, } \\
\text { 2013)) }\end{array}$ \\
\hline $\begin{array}{l}\text { Insulation, window type, primary heating } \\
\text { fuel, draught proofing, lighting, etc. }\end{array}$ & Energy Performance Certificates (EPCs) (DCLG, 2017) \\
\hline $\begin{array}{l}\text { Characteristics otherwise assumed based } \\
\text { on dwelling age and form (e.g., actual } \\
\text { consumption values, loft insulation, } \\
\text { occupant count, and boiler efficiency). }\end{array}$ & $\begin{array}{l}\text { Home occupant questionnaires - Number of occupants, } \\
\text { insulation details, boiler type, secondary systems, } \\
\text { heating set-point, solar energy systems, etc. }\end{array}$ \\
\hline
\end{tabular}

To simplify data collection, assumptions are made where data is not generally available. Examples of assumptions made in the model include:

- heating set-point, unless known, is assumed to be $21^{\circ} \mathrm{C}$ (as default in the BREDEM-12 model and SAP);

- occupancy, unless gathered from occupant survey, is calculated from floor area using the BREDEM-12 method;

- street-facing windows and frames are directly observed but all other unseen windows are assumed to be the same; wall construction and U-values (unless known, e.g. reported in EPCs) are based on the age of the home where construction methods are well documented (e.g. BREDEM reference tables);

- if the home has double glazing which is easily observed, then the home has at least $100 \mathrm{~mm}$ of loft insulation (this is to reflect the large amount of homes which have up to $100 \mathrm{~mm}$ of loft insulation installed (over 90\%) (Palmer and Cooper, 2013). EPC information or survey data on loft insulation supersedes this assumption; 
- if the home has a solar hot water system, then the domestic hot water tank (assumed) has foam insulation (at least $35 \mathrm{~mm}$ ).

Some limitations of DECoRuM include:

- Depending on the level of precision desired, desktop data collection and entry (e.g. entries from façade observations) can be time intensive; however distributed questionnaires on dwelling characteristics (especially externally unobservable characteristics) can be helpful.

- Behaviour assessment is limited: occupancy times, heating schedules, window opening schedules, etc. are not modelled.

- Assumptions are made about occupant behaviour, e.g. temperature set-point; however, it can be modelled and collected via survey.

- The model does not calculate where specifically a homeowner should insulate walls and whether internal or external insulation is ideal (insulation is simply entered as $U$-value).

- Different scenarios must be calculated separately and cannot vary within a given timeframe; calculations are static.

Furthermore, the limitation of the approach is that the overall model takes an aggregated look at neighbourhood performance and retrofit potential. Detailed house-by-house assessment would require in-person inspection and detailed modelling.

Calibration of the energy model is done by aligning the mean $\mathrm{CO}_{2} \mathrm{e}$ emissions of all dwellings calculated using DECoRuM with the mean of the total $\mathrm{CO}_{2} \mathrm{e}$ emissions as calculated from the subnational energy consumption data at lower layer super output area (LSOA) level (BEIS, 2019). The results for each household are displayed on a map using GIS software; in this instance Maplnfo Professional Version 10.5.2. GIS allows any variable that is collected or calculated to be mapped for visual communication, e.g. kWh p.a., $\mathrm{CO}_{2} \mathrm{e}$ emissions $\mathrm{m}^{-2}$ p.a., homes in need of cavity wall insulation, PV suitability etc. Beyond establishing the baseline energy use, potential for further domestic energy reductions in that area can be modelled and mapped. This is done by changing specified characteristics in the model to calculate the impact of improvement through single measures or packages.

Overall, in this study, DECoRuM was used to:

1. Estimate baseline domestic $\mathrm{CO}_{2} \mathrm{e}$ emissions for the selected area on a house-by-house level

2. Estimate the aggregated emissions for the area following the application of whole house retrofit with the intent to achieve net-zero

\subsection{Retrofit modelling}

As a starting point to create a list of measures to be modelled for retrofit, the ECO3 measure table provided by Ofgem ${ }^{2}$ was used as ECO3 is the current version of the obligation for the period of 2018-2022. The Ofgem table provides information on the energy efficiency measures which suppliers can install to meet their ECO3 obligations. The modelled measures are wall insulation, loft insulation, draught proofing, improved window glazing (from single to double), heating system upgrade (including pipework insulation, heating controls, $90 \%$ efficiency boiler, hot water tank insulation), and PV. As ECO3 will not be enough to meet the UK government's obligation to be netzero by 2050 a more radical retrofit package is designed to include relevant ECO3 measures and additional measures to make up the whole house retrofit package (Table 4). A brief overview of

\footnotetext{
${ }^{2}$ www.ofgem.gov.uk/system/files/docs/2018/12/eco3_measures_table_v3.1.pdf
} 
rough cost estimates will also be provided. The cost for each measure were taken from Currie \& Brown and AECOM (2019); (Palmer et al., 2017)

Table 4. Whole house retrofit package using a combination of energy efficiency measures and renewables (Currie \& Brown and AECOM, 2019)

\begin{tabular}{|c|c|c|c|}
\hline $\begin{array}{l}\text { Adopted } \\
\text { measure }\end{array}$ & Addresses & Model improvements & Modelled units \\
\hline \multirow{2}{*}{ Fabric } & \multirow{2}{*}{$\begin{array}{l}\text { Space } \\
\text { heating } \\
\text { efficiency }\end{array}$} & $\begin{array}{l}\text { Draughtproofing / seal } \\
\text { openings (e.g. fireplaces) } \\
\text { Improve airtightness }\end{array}$ & $1.0 \mathrm{~m}^{3} \mathrm{~h}^{-1} \mathrm{~m}^{-2} @ 50 \mathrm{pa}$ \\
\hline & & \multicolumn{2}{|c|}{ 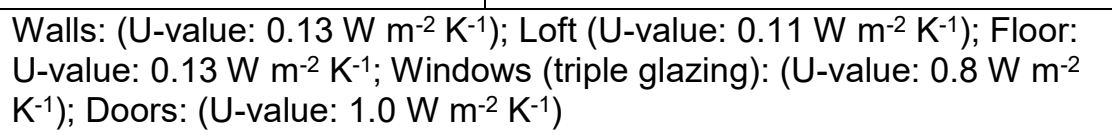 } \\
\hline \multirow{4}{*}{ Systems } & $\begin{array}{l}\text { Space } \\
\text { heating }\end{array}$ & $\begin{array}{l}\text { Air source heat pump (UK } \\
\text { expected to abandon gas } \\
\text { boilers as heating solution } \\
\text { (Early, 2020)) }\end{array}$ & $\begin{array}{l}\text { Coefficient of Performance (COP) = } 2.6 \\
\text { (Greater London Authority, 2018); RHI } \\
\text { payment } £ 0.107 \text { per kWh through June } \\
2020 \text { (Ofgem, 2020). }\end{array}$ \\
\hline & $\begin{array}{l}\text { Water } \\
\text { heating }\end{array}$ & $\begin{array}{l}\text { Jacket insulation on hot } \\
\text { water tank, insulated } \\
\text { pipework, cylinder thermostat }\end{array}$ & $80 \mathrm{~mm}$ jacket insulation \\
\hline & $\begin{array}{l}\text { Electricity } \\
\text { efficiency }\end{array}$ & Low energy light bulbs & $100 \%$ low LED \\
\hline & $\begin{array}{l}\text { Electricity } \\
\text { production }\end{array}$ & Photovoltaics & $\begin{array}{l}\text { PV kWp dependent on roof capacity; } \\
50 \% \text { self-consumption (Gupta et al., } \\
2019 \text { ) }\end{array}$ \\
\hline
\end{tabular}

\section{Results}

\subsection{Top-down assessment: characteristics of the selected area}

Using the top down publicly available datasets, rapid energy assessment was undertaken for the case study area. Table 5 shows the sub-national data comparisons between the case study area, City of Oxford and Oxfordshire (county in which Oxford city falls in). The RH case study area was found to have lower gas consumption as compared to Oxfordshire up to $30 \%$ less than the mean and only $3 \%$ less than the Oxford City mean. However, with $11.8 \%$ fuel poor households, RH has a higher level of fuel poverty than the Oxfordshire mean but less than Oxford city mean. The city of Oxford has the highest levels of fuel poverty within Oxfordshire; the 15 LSOAs with the highest fuel poverty (above 18\%) are all located in Oxford City. Rose Hill data also show (in parenthesis) the rank of the neighbourhood amongst the LSOAs in Oxfordshire. With respect to rankings, Rose Hill mapped area is most relevant regarding fuel poverty.

The dwellings for which there are EPCs available in the RH area $(n=180)$ have a lower EPC rating than the city and the county but have a higher efficiency rating potential from EPC recommended measures. Home ownership and social/council rent are both slightly below the mid-range for Oxford. Employment and retirement are high in the area relative to Oxford and Oxfordshire. Sick 
and disabled is also very high but may correspond with retirement. This indicates that the selected area is predominantly fuel poor, socially deprived and there is potential for energy retrofits to reduce fuel costs and tackle fuel poverty.

Table 5. Sub-national energy and economic classification data (BEIS, 2017; ONS, 2016).

\begin{tabular}{|c|c|c|c|c|}
\hline & $\begin{array}{l}\text { Data } \\
\text { density }\end{array}$ & Rose Hill & Oxford city & Oxfordshire \\
\hline $\begin{array}{l}\text { Mean gas } \\
\text { consumption }\end{array}$ & LSOA* $^{*}$ & $\begin{array}{l}12,455 \mathrm{kWh} \\
\text { (Oxford rank } 55 \text { of } 83 \text { ) }\end{array}$ & $13,775 \mathrm{kWh}$ & $14,198 \mathrm{kWh}$ \\
\hline $\begin{array}{l}\text { Mean elec. } \\
\text { Consumption }\end{array}$ & LSOA & $\begin{array}{l}3,064 \mathrm{kWh} \\
\text { (Oxford rank } 80 \text { of } 83 \text { ) }\end{array}$ & 3,666 kWh & $4,322 \mathrm{kWh}$ \\
\hline Mean fuel poverty & LSOA & $\begin{array}{l}11.8 \% \\
\text { (Oxford rank } 38 \text { of } 83 \text { ) }\end{array}$ & $12.9 \%$ & $9.6 \%$ \\
\hline Dwelling owned & $\mathrm{MSOA}^{* *}$ & $\begin{array}{l}55 \% \text { (Oxford rank } 7 \text { of } 18 \text { ) } \\
\text { (Oxfordshire rank } 111 \text { of } 130 \text { ) }\end{array}$ & $47 \%$ & $68 \%$ \\
\hline $\begin{array}{l}\text { Social / council } \\
\text { rent }\end{array}$ & MSOA & $\begin{array}{l}41 \% \text { (Oxford rank } 6 \text { of } 18 \text { ) } \\
\text { (Oxfordshire rank } 12 \text { of } 130 \text { ) }\end{array}$ & $36 \%$ & $18 \%$ \\
\hline Employed & MSOA & $\begin{array}{l}\text { (Oxford rank } 2 \text { of } 18 \text { ) } \\
\text { (Oxfordshire rank } 23 \text { of } 130 \text { ) }\end{array}$ & & \\
\hline Full time students & MSOA & $\begin{array}{l}\text { (Oxford rank } 9 \text { of } 18 \text { ) } \\
\text { (Oxfordshire rank } 15 \text { of } 130 \text { ) }\end{array}$ & & \\
\hline Retired & MSOA & $\begin{array}{l}\text { (Oxford rank } 2 \text { of } 18 \text { ) } \\
\text { (Oxfordshire rank } 72 \text { of } 130 \text { ) }\end{array}$ & & \\
\hline Sick / disabled & MSOA & $\begin{array}{l}\text { (Oxford rank } 4 \text { of } 18 \text { ) } \\
\text { (Oxfordshire rank } 5 \text { of } 130 \text { ) }\end{array}$ & & \\
\hline Mean EPC band & $\begin{array}{l}\text { Dwelling } \\
\text { level }\end{array}$ & $\mathrm{D}(63)$ & $\mathrm{D}(65)$ & $\mathrm{D}(64)$ \\
\hline $\begin{array}{l}\text { Mean EPC band } \\
\text { potential }\end{array}$ & $\begin{array}{l}\text { Dwelling } \\
\text { level }\end{array}$ & C (78) & C (75) & C (77) \\
\hline
\end{tabular}

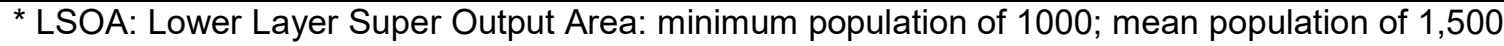

${ }^{* *}$ MSOA: Middle Layer Super Output Area: minimum population of 5,000; mean population of 7,200

In the case study area, just over half of all dwelling types are terraced with 1930s terraced dwellings making up almost half of the area (Figure 2). Flats have an equal proportion of converted and purpose-built (PB) flats. The 'other (mix)' mostly comprises dwellings built after the 1980s. 

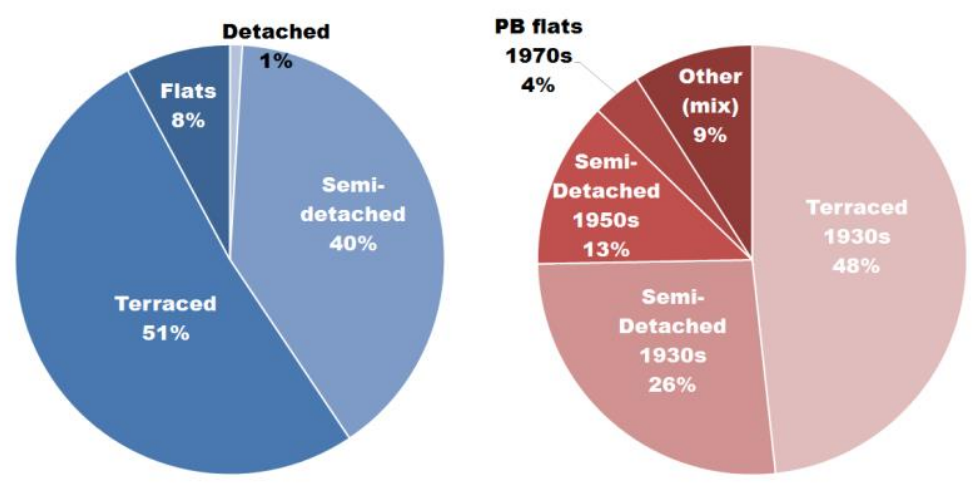

Figure 2. Dwelling types prevalent in the case study area

Figure 7 shows the distribution of energy efficiency ratings (EER) for all EPCs in Oxford and RH. The shift in potential EER is toward a mode of 84 (B rating) whereas the current EER mode is 61 ( $D$ rating). While the mean for current levels of energy efficiency in the mapped area is slightly lower (2 points) than the corresponding mean for the city of Oxford, the mean for potential energy efficiency is two points higher, again re-affirming the significance of energy retrofits.
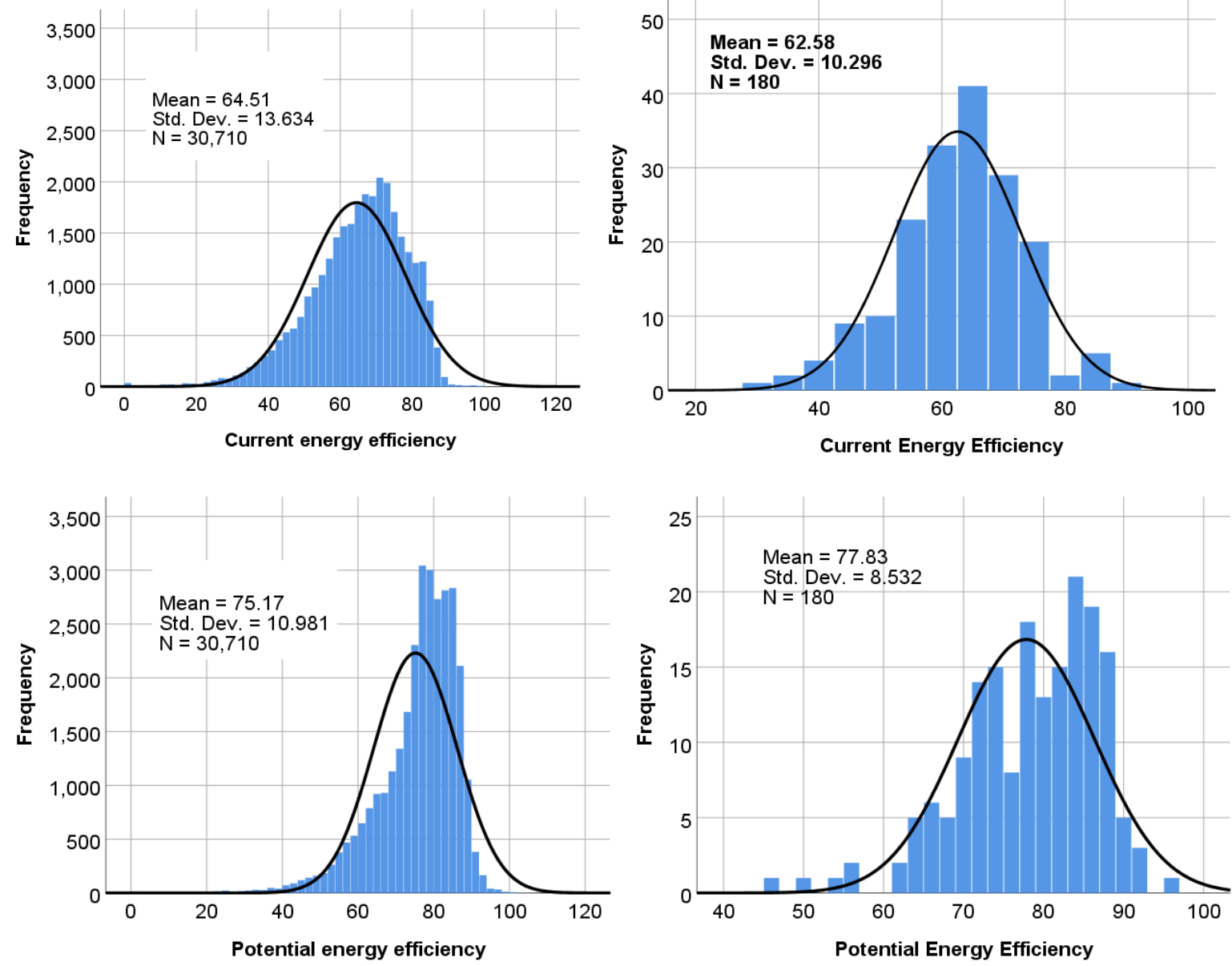


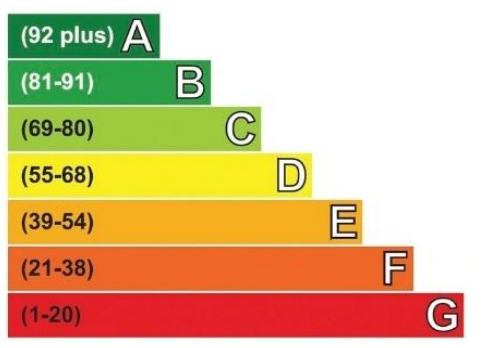

EPC Energy Efficiency

Rating (EER) scale

provided for reference

Figure 3. Current and potential energy efficiency ratings in EPC for Oxford city (left) and RH area (right) (MHCLG, 2017).

In addition to understanding the energy profile of the case study area, it is also necessary to understand the socio-economic characteristics of the mapped area to help with the take-up of retrofit measures. Figure 4 shows socio-economic data for the mapped area broken down by postcode level. Generally, higher income households, which also have a higher proportion of outright owned or mortgaged dwellings, are located on the north end of the mapped area and lower income households, which include a higher proportion of social housing tenant, are located at the south. Given the priority to deal with fuel poverty, the south portion of the mapped area is likely to be eligible for ECO funding (public funding). Households lying in the north portion of the mapped area are more likely able to pay for retrofit work (able to pay).

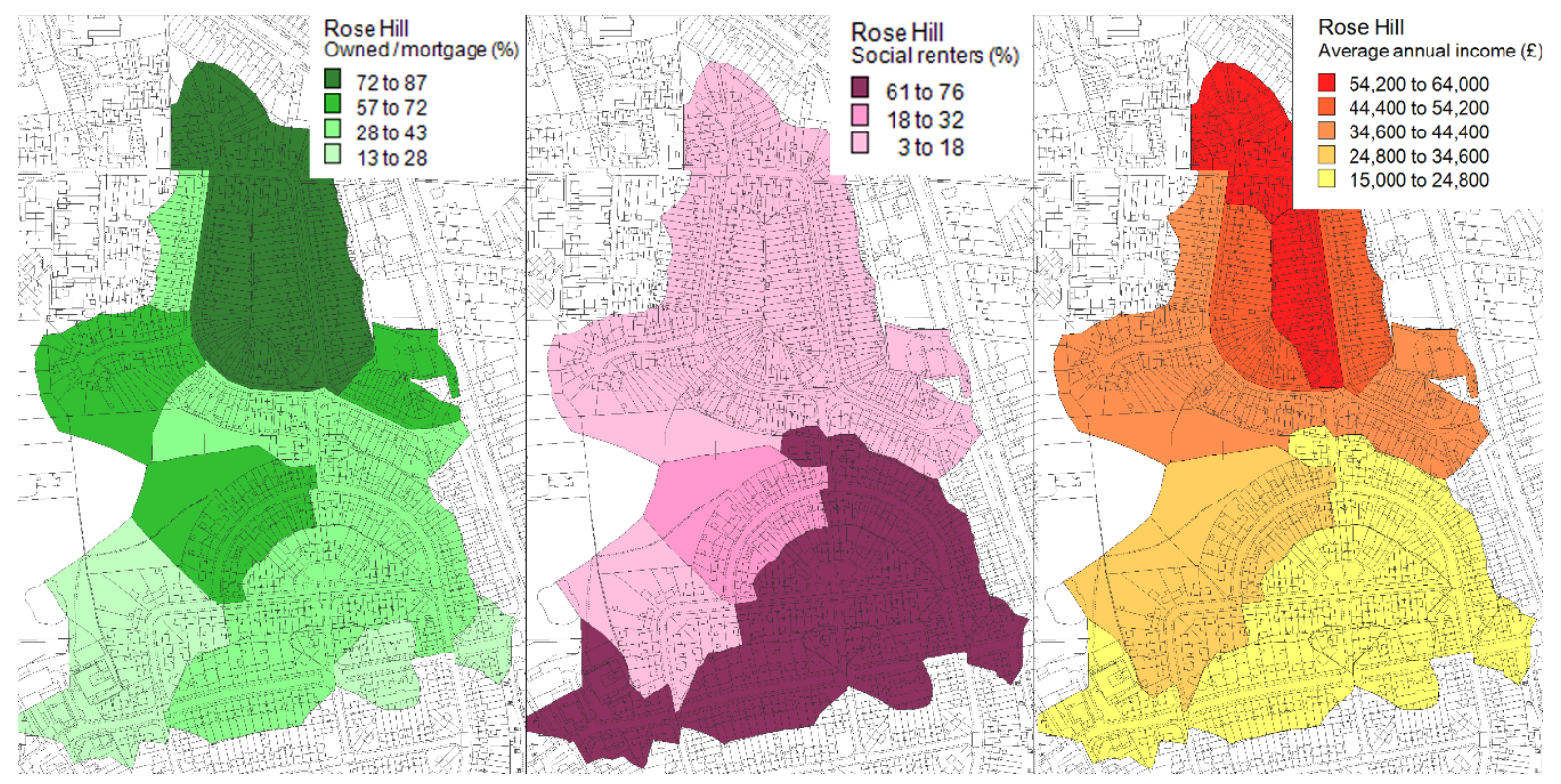

Figure 4 Socio-economic data (CACl, 2020); Map@ Crown Copyright and Database Right 2018. Ordnance Survey (Digimap Licence).

Further segmentation of the socio-economic characteristics of households is vital for effective targeting of retrofits. The Acorn dataset in the UK defines 59 socio-economic groups nationally by consumer and community behavior (CACl, 2020). There are 11 of these groups represented in the mapped area. The percentage data are based on national statistics for each type. Figure 5 shows postcode assignment for each of the 11 groups. Generally, as the number increases, the claimed benefits increase and the annual income decreases. The percentage of households that claim benefits range from $1.5 \%$ in group 1 to $14 \%$ in group 11. Again, benefit recipients are the focus of ECO funding. Figure 5 also shows some additional statistics for the groups. Interestingly the effort to cut down on energy consumption in the home tracks disposable income, implying that those with higher proportion to disposable income also tend to make an effort to cut down on energy use since they are more likely to be aware about climate change and environmental agenda. Category 7 , majority student population, has the lowest energy reduction effort and disposable income. This 
again reinforces the need to examine the retrofit potential for such dwellings, where physical upgrades can lead to lower energy costs.
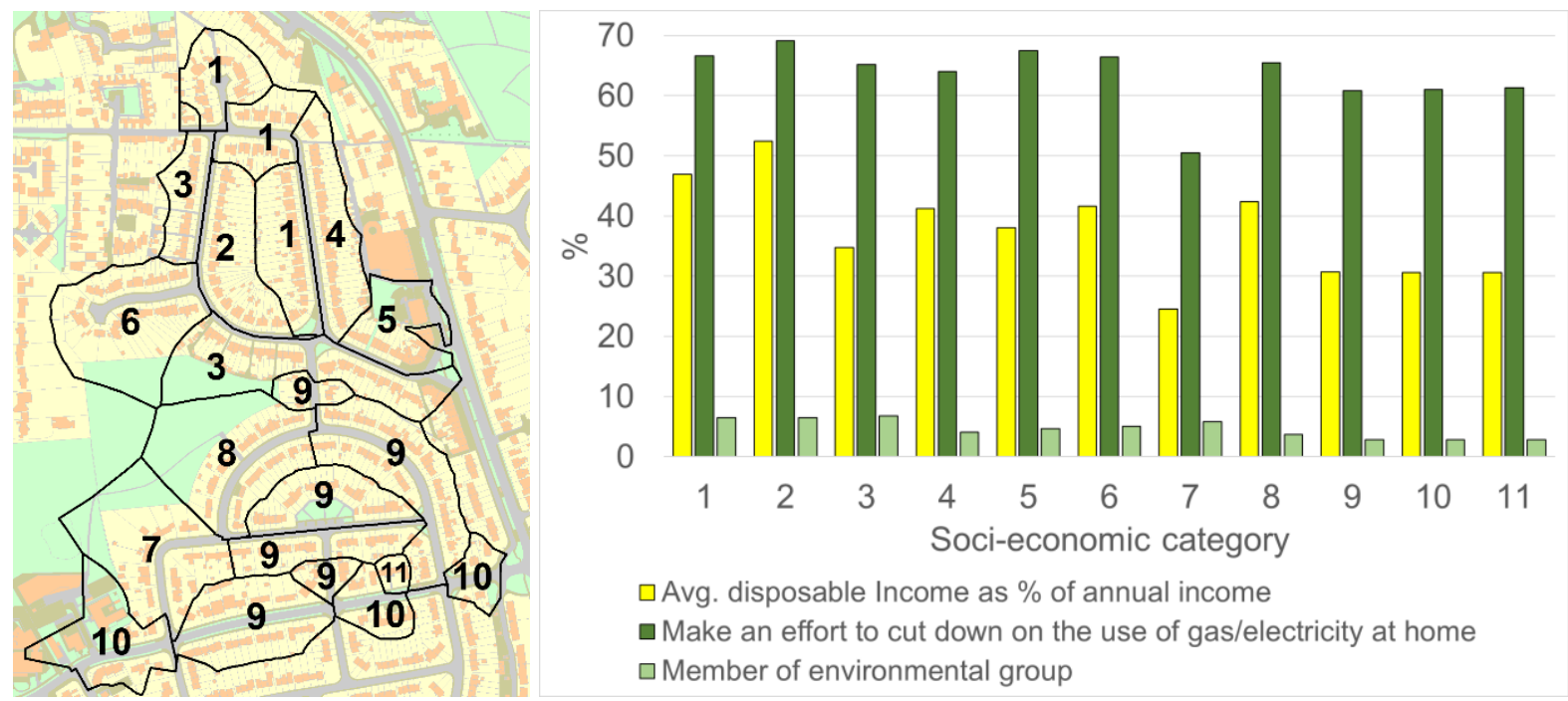

$\square$ Avg. disposable Income as \% of annual income

$\square$ Make an effort to cut down on the use of gas/electricity at home

$\square$ Member of environmental group

Figure 5. Socio-economic classification types by postcode (CACl, 2020); Map@ Crown Copyright and Database Right 2018. Ordnance Survey (Digimap Licence).

\subsection{Home energy questionnaire results}

The online questionnaire received 41 responses with 28 in the actual mapped boundary ('Rose Hill' is a much larger area than the 431 dwellings in the final mapped area). In total, 57 questions were asked; most responses are used for improving the model inputs. Table 6 lists a few statistically important questions and the responses. Insulation age informs U-value assumptions, e.g. loft insulation before 2008 is assumed to be $150 \mathrm{~mm}$, after 2008 is assumed to be up to $250 \mathrm{~mm}^{3}$. Most dwellings surveyed have double glazing; however, when asked about the proportion of single glazing some of those with double glazing $(n=8)$ still had $50 \%$ or less single glazed windows. Boiler age informs heating systems efficiency assumptions, e.g. before 1998 is assumed to be $0.7-0.78$ (depending on age of dwelling), between 1998-2005 is assumed to be 0.85 , between $2005-2010$ is 0.88 , and after 2010 is 0.9 . Finally, all but two dwellings heat with gas, the other two using electricity. Half of the households use a secondary heating source in their home.

Table 6. Results of the home energy questionnaire survey ( $n=41$ responses).

\begin{tabular}{|c|c|}
\hline Question & RESPONSE \\
\hline No. of occupants & 2.2 (average) \\
\hline Age of dwelling & $\begin{array}{l}\text { Built age: } 1930-1949:(n=34) ; 1970-1989:(n=4) ; 2010 ;(n=1) \\
1930 \text { (mode); } 1935 \text { (median) }\end{array}$ \\
\hline Construction & Brick cavity $(n=37)$; brick solid $(n=4)$ \\
\hline Loft insulation & $\begin{array}{l}\text { Installed before } 2008(n=13) ; \text { Installed after } 2008(n=19) ; \text { None } \\
(n=2) ; \text { unknown }(n=6)\end{array}$ \\
\hline Wall insulation & Installed before $2008(n=9) ;$ Installed after $2008(n=8)$; None \\
\hline
\end{tabular}

${ }^{3} 2008$ marked the beginning of the Carbon Emissions Reduction Target; predecessor to ECO (Ofgem, 2019b). 


\begin{tabular}{|c|c|}
\hline & $(n=7) ;$ unknown $(n=16)$ \\
\hline Draught proofing & All $(n=14)$; Most $(n=9)$; Some $(n=6)$; None $(n=8)$ \\
\hline Glazing & Triple $(n=1)$; Double $(n=33)$; Single $(n=4)$ \\
\hline Boiler & $\begin{array}{l}\text { Installed before } 1998(n=4) ; \text { Inst. between 1998-2005 }(n=7) \text {; Inst. } \\
\text { between 2005-2010 (n=8); Inst. after } 2010(n=19) ; \text { no boiler }(n=3)\end{array}$ \\
\hline Thermostat setting & $19^{\circ} \mathrm{C}$ (median); $19.3^{\circ} \mathrm{C}\left(\right.$ mean) ${ }^{*}$ \\
\hline Average cost of energy bills & $£ 925$ (median); £992 (mean); no response $(n=10)$ \\
\hline Annual gas consumption ${ }^{4}$ & $8,416 \mathrm{kWh}$ (median); 10,438 kWh (mean); no response $(\mathrm{n}=27)$ \\
\hline Annual electricity consumption & 2,392 kWh (median); 2,652 kWh (mean); no response $(\mathrm{n}=27)$ \\
\hline $\begin{array}{l}\text { Does the cost of fuel influence } \\
\text { how you heat your home? }\end{array}$ & Yes $(n=26) ;$ No $(n=15)$ \\
\hline $\begin{array}{l}\text { Is } 10 \% \text { or more of your annual } \\
\text { net income used to pay energy } \\
\text { bills? }\end{array}$ & Yes $(n=7) ;$ No $(n=32) ;$ no response $(n=2)$ \\
\hline $\begin{array}{l}\text { Are you interested in energy } \\
\text { efficiency work and would you } \\
\text { like to be contacted? }\end{array}$ & Yes $(n=28) ;$ No $(n=13)$ \\
\hline
\end{tabular}

${ }^{*}$ As can be seen here, the mean heating set-point is lower than the assumed modelling set-point; validating the process of lowing the set-point to calibrate the model.

\subsection{Baseline energy model and retrofit potential}

Using DECoRuM modelling, the total mean annual energy consumption in the mapped area is found to be $18,849 \mathrm{kWh}$ p.a. or $173 \mathrm{kWh} \mathrm{m}^{-2}$ p.a. The mean annual $\mathrm{CO}_{2} \mathrm{e}$ emissions for $\mathrm{RH}$ area is $3,821 \mathrm{kgCO}_{2}$ p.a. or $35 \mathrm{kgCO}_{2} \mathrm{~m}^{-2}$ p.a. The total mean annual gas consumption is calculated to 15,159 kWh p.a., which is between Ofgem's (Ofgem, 2019c) medium and high gas consumption value (Typical Domestic Consumption Values (TDCV)) for the UK. Total mean electricity consumption for the area is estimated to be 2,923 kWh p.a.; this is just below the medium electricity value for Ofgem's TDCV.

Figure 6 shows a colour-coded thematic map showing the house-by-house distribution of energy consumption for the dwellings in the mapped area. Nearly $38 \%$ of the dwellings are found to have annual $\mathrm{CO}_{2} \mathrm{e}$ emissions above $4000 \mathrm{kgCO}_{2}$ p.a. The figure also shows distribution of wall type. Most of the walls are found to need insulation, as grouped in the upper portion of the map. Interestingly this part of the case study area has a large proportion of owner-occupiers who form the 'able to pay' group.

\footnotetext{
${ }^{4}$ Respondents were asked to consult energy bills and instructed on how to do so
} 

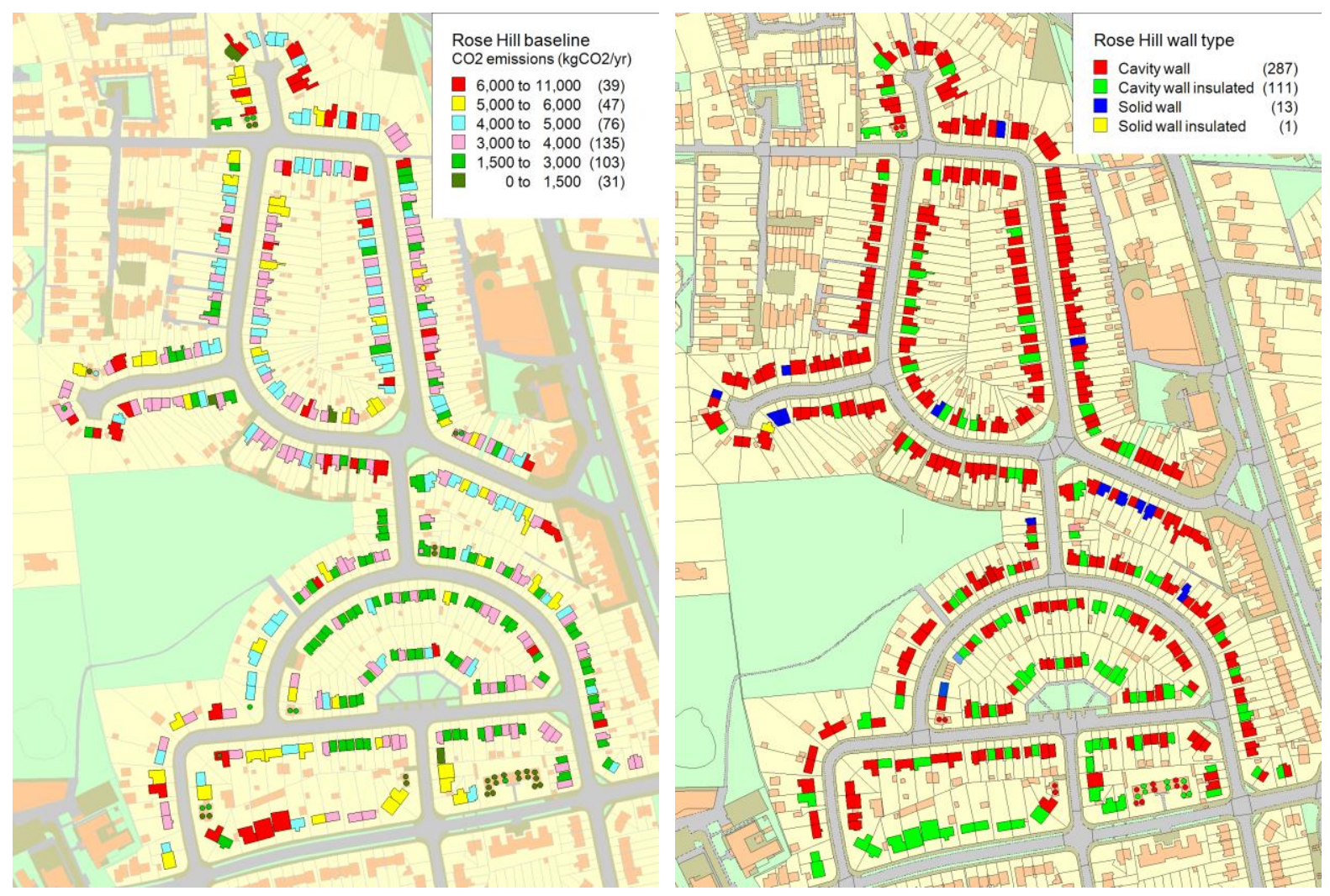

Figure 6. Coloured coded map showing house-by-house annual carbon emission (left) and by wall type (right). EPC data (MHCLG, 2017); Map@ Crown Copyright and Database Right 2018. Ordnance Survey (Digimap Licence).

By analysing physical characteristics and baseline energy model of the case study area, the house-by-house retrofit need is presented in Table 7. As an example, nearly 307 dwellings are found to be suitable for wall insulation, out of which cavity wall insulation can be deployed in 294 dwellings.

Table 7. Technical potential for retrofit measures in the case study area

\begin{tabular}{|l|l|l|l|l|}
\hline MEASURE & DWELLINGS & MEASURE & DWELLINGS \\
\hline Uninsulated cavity walls & $294(68 \%)$ & Loft insulation thickness <200mm & $112(26 \%)$ \\
\hline Uninsulated solid walls & $13(3 \%)$ & $\begin{array}{l}\text { Boiler efficiency <0.85 (potential for boiler } \\
\text { upgrade) }\end{array}$ & $247(57 \%)$ \\
\hline $\begin{array}{l}\text { Single glazing (potential } \\
\text { for double or triple) }\end{array}$ & $72(17 \%)$ & Potential for PV & $335(78 \%)$ \\
\hline $\begin{array}{l}\text { Double glazing (potential } \\
\text { for triple) }\end{array}$ & $358(83 \%)$ & $\begin{array}{l}\text { Full whole house package where some } \\
\text { degree of each measure is needed (see } \\
\text { methods) }\end{array}$ & $300(70 \%)$ \\
\hline
\end{tabular}

Two scenarios for whole house retrofits were investigated. Firstly a retrofit package under current ECO policy was developed that includes wall and loft insulation, draught proofing, improved window glazing (from single to double), heating system upgrade (including pipework insulation, $90 \%$ efficiency boiler, hot water tank insulation), and rooftop solar PV. Secondly, a more ambitious whole house retrofit package based on Table 4 was deployed. This package included the 
deployment of heat pump and a more stringent building fabric upgrade. Table 7 summarises the results of the two retrofit packages. Unsurprisingly the whole house retrofit package led to much higher reduction in energy use and carbon emissions than the ECO retrofit package, amounting to almost $95 \%$ energy and 95\% carbon reduction over the baseline energy use and emissions. The whole house retrofit approach also resulted in an $87 \%$ mean reduction in energy bills (as against $38 \%$ from ECO retrofit package) which is a significant benefit to fuel poor households.

Table 8. Results following the application of ECO retrofit package and whole house retrofit package

\begin{tabular}{|l|l|l|}
\hline & \multicolumn{1}{|c|}{ ECO retrofit package } & \multicolumn{1}{|c|}{ Whole house retrofit package } \\
\hline $\begin{array}{l}\text { Energy } \\
\text { consumption }\end{array}$ & $\begin{array}{l}10,614 \mathrm{kWh} \text { p.a.; } 95 \mathrm{kWh} \mathrm{m}^{-2} \text { p.a.; } \\
44 \% \text { reduction }\end{array}$ & $\begin{array}{l}982 \mathrm{kWh} \text { p.a.; } 11 \mathrm{kWh} \mathrm{m}^{-2} \text { p.a.; } \\
95 \% \text { reduction }\end{array}$ \\
\hline $\begin{array}{l}\mathrm{CO}_{2} \mathrm{e} \\
\text { emissions }\end{array}$ & $\begin{array}{l}2,179 \mathrm{kgCO}_{2} \text { p.a.; } 20 \mathrm{kgCO}_{2} \mathrm{~m}^{-2} \text { p.a.; } \\
43 \% \text { reduction }\end{array}$ & $\begin{array}{l}226 \mathrm{kgCO}_{2} \text { p.a.; } 3 \mathrm{kgCO}_{2} \mathrm{~m}^{-2} \text { p.a.; } \\
94 \% \text { reduction }\end{array}$ \\
\hline
\end{tabular}

Figure 7 shows the distribution of house-by-house carbon emissions in the mapped area following the application of the whole house retrofit package in the energy model of each dwelling. Within the whole retrofit package, there are two sub-scenarios modelled - one with $50 \%$ self-consumption of solar PV electricity in line with the Government approved SAP model for producing energy rating of dwellings, and also another with $100 \%$ self-consumption of PV electricity assuming load shifting of energy end uses to utilise all the solar PV electricity generated. Interestingly under a $100 \%$ selfconsumption scenario, a significant number of dwellings ( $n: 343$ ) are found to have annual carbon emission below $300 \mathrm{kgCO}_{2}$ p.a. as compared to 44 dwellings in the whole house retrofit subscenario with $50 \%$ self-consumption of PV electricity. 


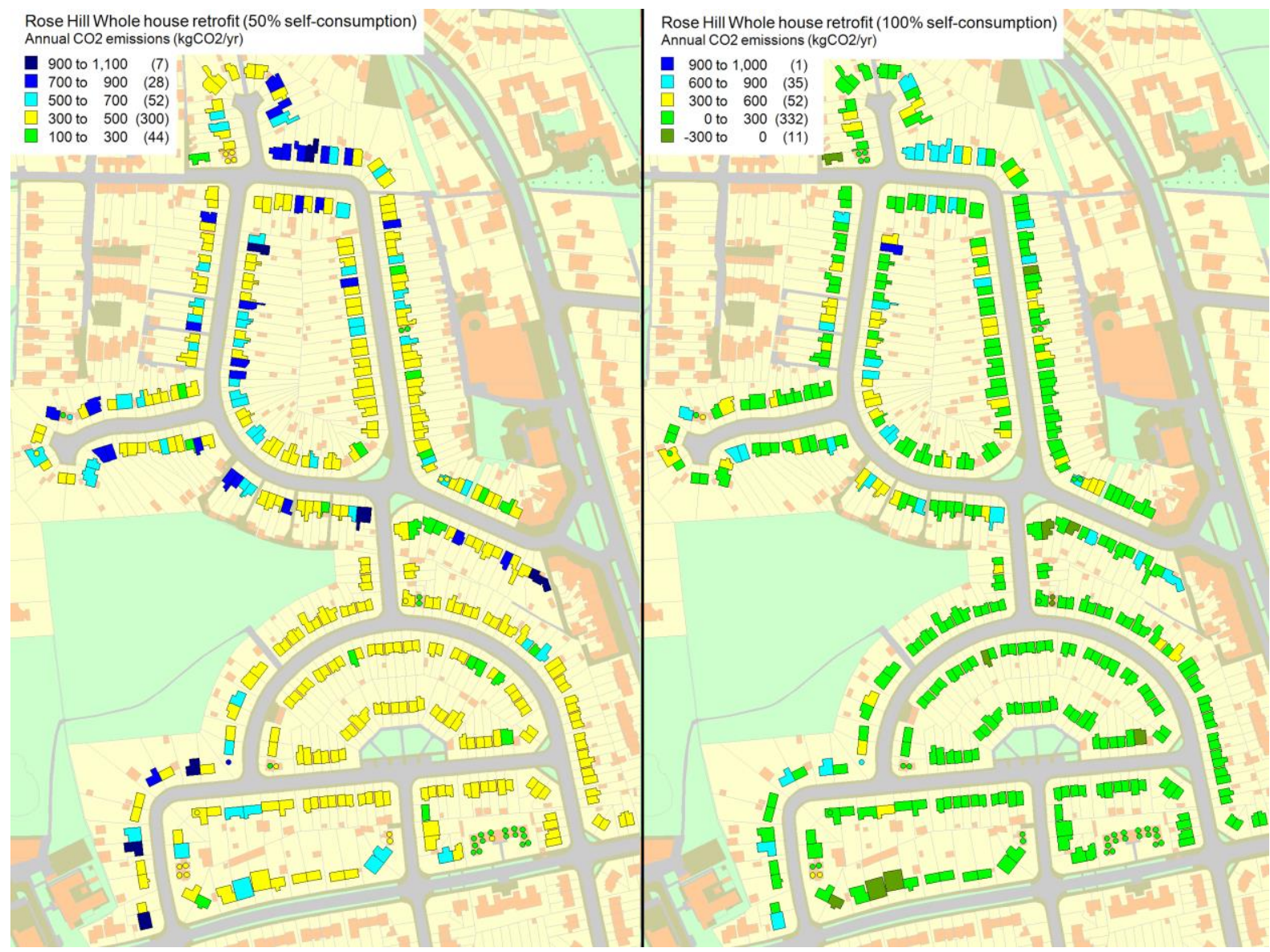

Figure 7. Thematic map showing the distribution of whole house retrofit in the case study area (50\% selfconsumption of solar PV on left, $100 \%$ self-consumption of solar PV right). EPC data (MHCLG, 2017); Map@ Crown Copyright and Database Right 2018. Ordnance Survey (Digimap Licence).

To develop an organised approach for targeting energy retrofits for a local area, dwellings in the case study area were grouped into common dwelling typologies for which more detailed analysis was conducted in terms of baseline energy use, retrofit potential and household annual income to get some idea of the ability to pay for the retrofit. Four dwelling typologies were identified as categorised by built form and age-band: 1930-1949 Terrace; 1930-1949 Semi-detached; 1950-1965 Semi-detached and 1966-1976 Flat. These four typologies cover 387 dwellings (90\%) of the total 431 mapped. The remaining dwellings consist of a mix of terraced housing from the 1950s - 1970s and newly built dwellings or converted flats that make up infill ranging in age from 1990s - 2000s.

The spatial distribution of the four typologies is shown in Figure 8 (left) and superimposed with household income group (from Figure 4) in Figure 8 (right). Interestingly a significant proportion of 1930-1949 terraced and 1930-1949 semi-detached falls in northern part of the case study area, which is supposed to be more affluent, with household annual income is above $£ 34,600$. 

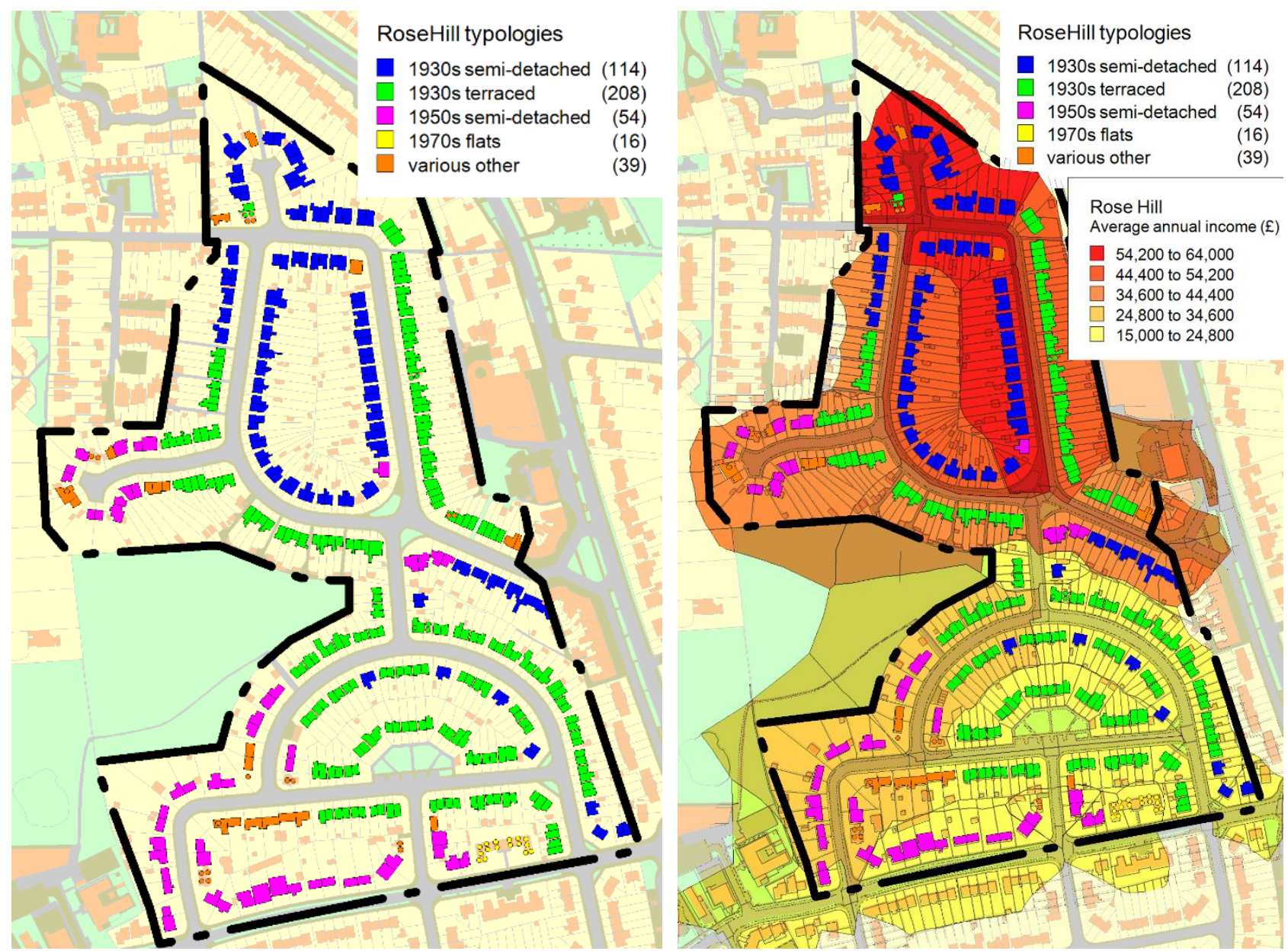

Figure 8. Common typologies (left) and common typologies with annual household income overlay (right). Map@ Crown Copyright and Database Right 2018. Ordnance Survey (Digimap Licence)

The modelling results in terms of baseline energy use and retrofit potential for the four identified typologies are summarised in Table 9 along with key physical characteristics that are relevant for targeting retrofits. It is interesting to observe that the two dominant typologies, 1930-1949 Terrace and 1930-1949 Semi-detached, have the largest proportion of uninsulated cavity walls $(80 \%)$ and single glazing (34\%), and have a greater proportion of dwellings with EPC efficiency ratings of E and $F$, thereby implying a greater need for retrofit. This is why these two groups have the highest mean annual energy use of $176 \mathrm{kWh} \mathrm{m}^{-2}$ p.a. and $186 \mathrm{kWh} \mathrm{m}^{-2}$ p.a.

When the whole house retrofit package is applied to the baseline energy models of the four typologies, significant reductions in energy use are observed ranging from $87 \%$ to $95 \%$.

Particularly for the typology, 1930-1949 Terrace, nearly $94 \%$ reduction in energy use is estimated by applying a whole house retrofit package. About $77 \%$ of the households in this typology of dwellings are found to have an annual household income of $£ 40,000$ or above. As per ACORN (CACl, 2020), this economic category is at the threshold of economically 'comfortable' for which there is likely to be a greater uptake of energy retrofits. 
Table 9. Baseline energy use and retrofit potential for common dwelling typologies in the case study area (Images Google maps).

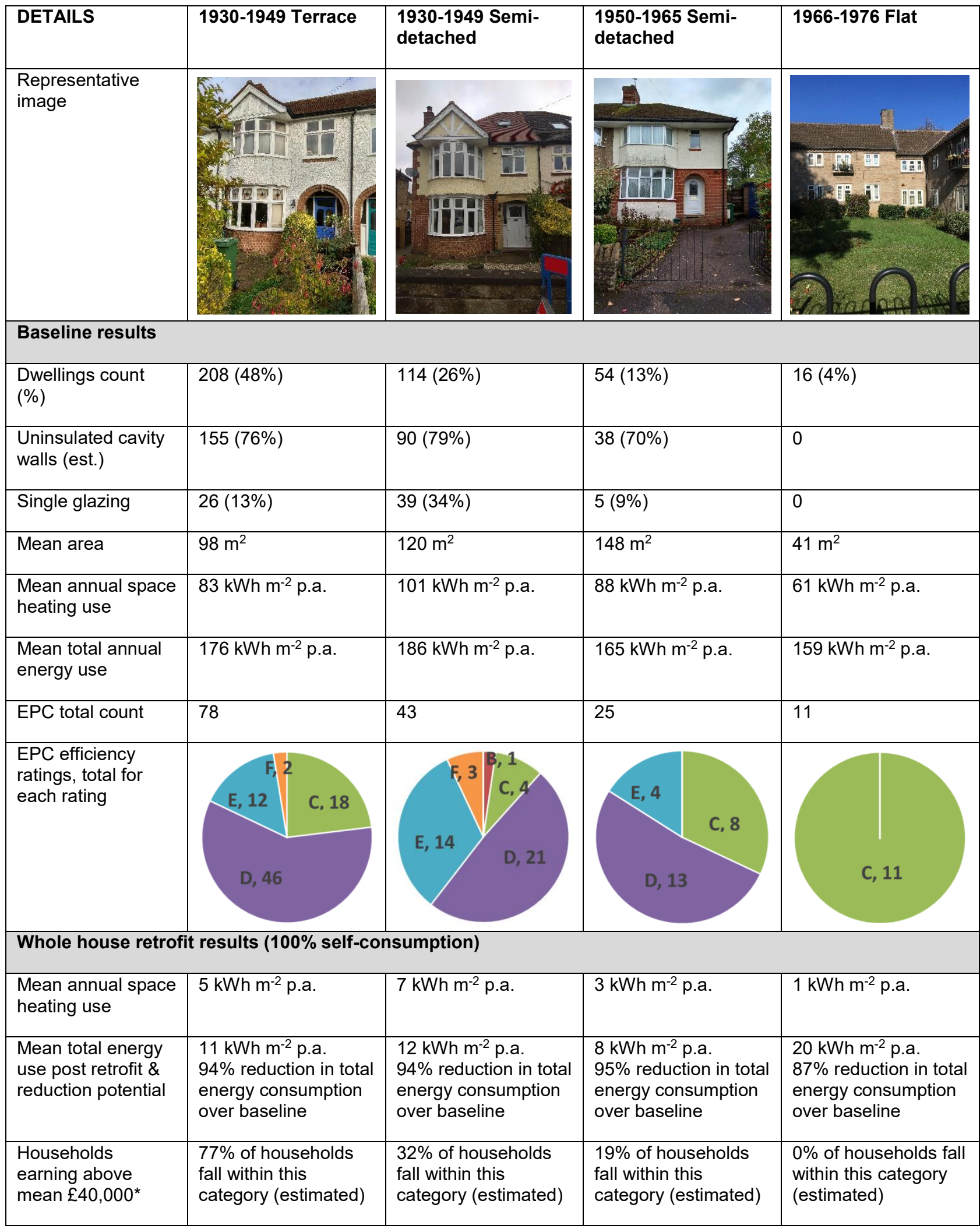

* $£ 40,000$ is based on the annual income of the economic category that is at the threshold of economically 'comfortable' and just above 'financially stretched' (CACl, 2020). For these there is an expected greater uptake of retrofit. 


\subsection{Targeting retrofit up-take}

To improve the targeting efficiency of energy retrofits which may help in lowering the cost of funding schemes such as ECO, different routes of identification were investigated. Domestic energy maps showing suitable dwellings for deploying single measures such as cavity wall insulation were produced as shown in Figure 6 (right). Such thematic maps could assist ECO obligated energy suppliers target appropriate households for single retrofit measures. Other routes for targeting retrofits could focus on high energy consumers, fuel poor households and specific dwelling typologies having high retrofit need.

Thematic maps can be used to geo-cluster highest energy consumers in the selected area. Figure 9 shows the energy consumption per area split into quartiles of baseline energy use. Wherein the first map shows dwellings in red that are in the top quartile of energy consumption, the distribution of high energy consumers is spread out. Since this does not show a clear area of focus, the second map shows the split at the median level of $175 \mathrm{kWh}$ $\mathrm{m}^{-2}$ p.a. A potential cluster is highlighted to the right - along this street, just over half of the dwellings are above the median threshold of energy use and can be targeted for energy retrofits.
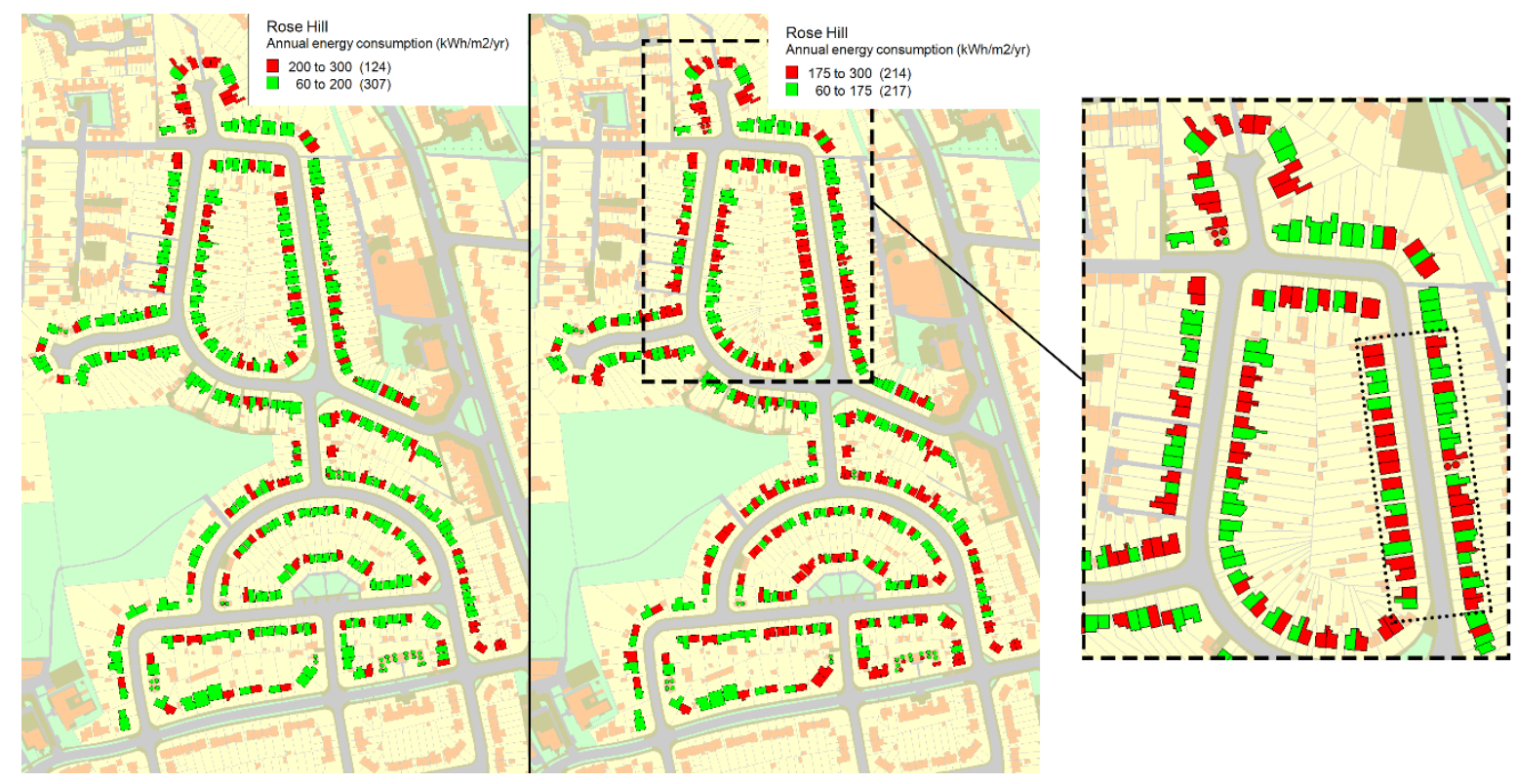

Figure 9. Identifying clusters of high energy consumers in the case study area. Map@ Crown Copyright and Database Right 2018. Ordnance Survey (Digimap Licence)

Current policies aimed at assisting the fuel poor are constrained in their ability to target fuel poor households. By superimposing relevant mapping layers, it is technically possible to pinpoint areas likely to have high levels of fuel poverty which could benefit from assistance to improve the energy efficiency of their homes. Figure 10 shows how national fuel poverty data at LSOA level is superimposed with socio-economic data at postcode level and upper quartile household energy consumption data (same as above) to identify cluster of dwellings with low annual household income, high energy use and high fuel poverty rate. Such areas can be targeted for funded energy retrofits through the ECO3 programme under which local authorities are also able to widen the eligibility criteria to tailor support measures to their area, often based upon income or health considerations. 


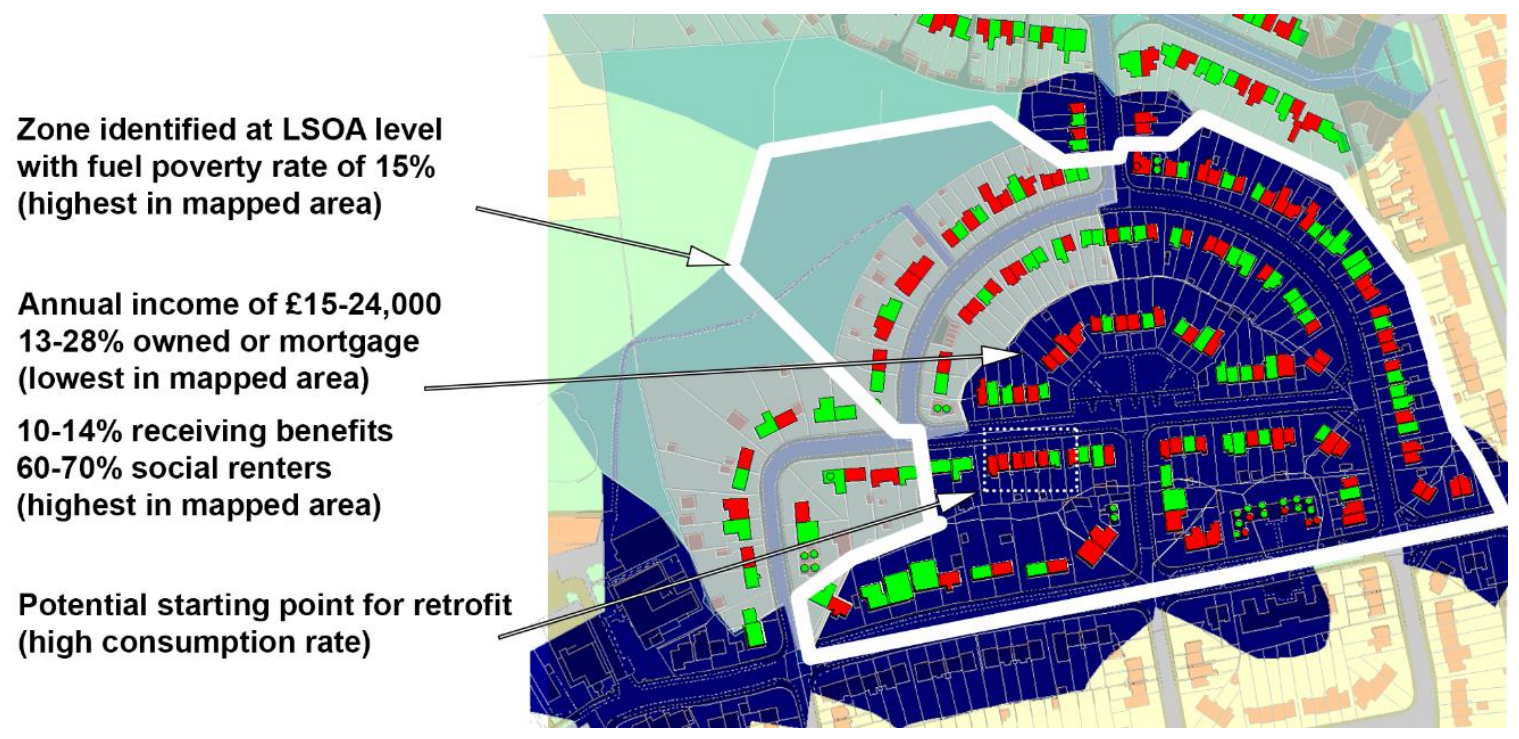

Figure 10. Superimposing different layers to identify fuel poor areas (CACl, 2020); Map@ Crown Copyright and Database Right 2018. Ordnance Survey (Digimap Licence)

Another way of increasing the uptake of retrofits is by identifying dwellings with similar typologies (with identical built form, age band) since they are expected to have similar need for energy retrofit. This may also bring economies of scale. Success will, however, be dependent on uptake from households. By superimposing data on annual household income for such dwellings, their ability to pay for the retrofit can be estimated indicating the likely take up of retrofit measures.

Figure 11 shows the common dwellings types, annual household income by postcode and all dwellings that are suitable for a whole house retrofit package (hatched dwellings). With the intent to roll out a mass retrofit programme for the most common dwelling type first, the image shows a street section where the whole house retrofit approach can be deployed. Theoretically, since this is a high-income area, there could be a greater uptake of energy retrofits. Within this identified area, those with high energy consumption can be further targeted to maximise energy reductions. 


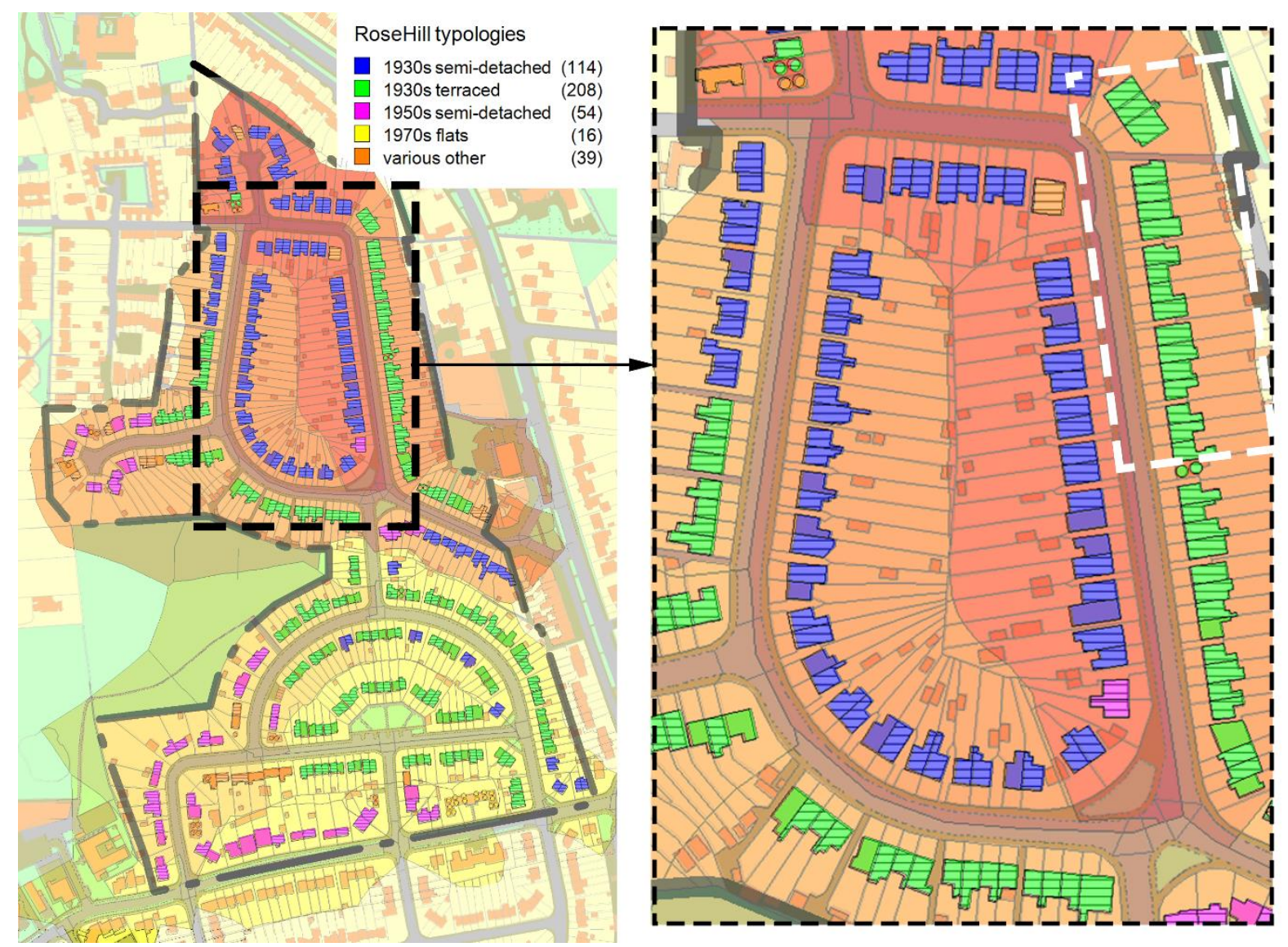

Figure 11. Superimposing common dwelling typologies Map@ Crown Copyright and Database Right 2018. Ordnance Survey (Digimap Licence).

Overall, the average cost to apply a whole house retrofit package in the mapped area is found to be $£ 25,500$. While the average cost to upgrade the building fabric alone is $£ 13,600$, the cost to install rooftop solar PV is about $£ 3,300$ (average size $2.6 \mathrm{kWp}$ ). Assuming the fuel cost for electricity as $£ 0.13$ per $\mathrm{kWh}$, the mean simple return on investment (ROI) for whole house retrofit in the entire area is around 40 years. This clearly points to the need for government grants, FiTs or other incentives. The £2 billion Green Homes Grant scheme, announced in July 2020 will be helpful in driving retrofit action. The scheme is designed to provide two thirds of the cost of energy efficiency-related home improvements to over 600,000 households with grants capped at $£ 5,000$ per household; higher for low income households with grants up to $£ 10,000$. Reducing the upfront cost in the area by $£ 5 \mathrm{k}$ and $£ 10 \mathrm{k}$ would reduce the simple ROI by 33 and 25 years respectively.

\section{Discussion}

To date it has proven difficult to rapidly identify suitable dwellings for energy retrofits despite the need for accelerating area-based low carbon retrofit programmes to meet the national and local climate emergency targets. The application of the domestic energy mapping approach in a neighbourhood in Oxford has shown how spatial mapping and urban energy modelling when combined with community engagement can create customised house-byhouse models that can be targeted for energy retrofits, be it ECO funded single measures or a whole house retrofit package. Such an approach supports UK Governments' recognition of the importance of local community groups and local government (Wade et al., 2013) in catalysing and supporting domestic energy reduction activities. The domestic energy mapping approach can also be used as means of sustaining engagement with community 
groups and local authorities by tracking retrofit installations and measuring the energy performance of homes post-retrofit by linking with smart meter data.

The concurrent analysis of multiple datasets related to rate of fuel poverty, socio-economic groups and annual/disposable household income along with physical characteristics and energy performance of dwellings, has revealed novel ways to improve the targeting efficiency of retrofit programmes such as ECO on upgrading the energy efficiency levels of fuel poor homes in the UK without pushing up the costs of the programme. Such multilayered analytics not only estimated the retrofit need on a house-by-house basis, but also estimated the potential for retrofit up-take in a local area depending upon local physicalsocio-economic characteristics. Identification of areas with high levels of fuel poverty, benefits recipients, and social housing with poor energy ratings are particularly helpful for the Home Heating Cost Reduction Obligation part of ECO, which is intended to reduce home heating costs for low income, fuel poor and vulnerable people (Ofgem, 2019a).

While ECO measures are designed to tackle fuel poverty, they will not be enough to meet the challenging target of net-zero, which is why a whole house retrofit package has been tested in this study. Although whole house retrofit can cost anywhere around $£ 70,000$ per home (Early, 2020), it is more costly to deploy piecemeal retrofit measures now and then reretrofit the same dwellings again later. The domestic energy mapping approach can enable aggregation of the demand for mass whole house retrofits thereby bringing economies of scale. By identifying dwellings with common physical characteristics and retrofit need, mass customisation can be developed. Retrofit kits such as mass-producible pre-manufactured façade solutions (e.g. Energiesprong (2019) coupled with mass retrofit effort could in theory reduce upfront costs. The UK Government will need to define a clear and consistent policy regarding whole house retrofit (IET, 2018) to sustain supply chains, and financially support the effort in the beginning (CCC, 2019).

Even with a whole house retrofit package, the neighbourhood area came close to achieving about $94 \%$ energy reduction, suggesting that net zero target will not be met by house-byhouse retrofit alone. Some level of local energy generation will be necessary possibly through roof mounted solar on community buildings or by deploying heat networks. This reaffirms the case for accelerating area-based low carbon retrofit programmes to drive early deployment of energy retrofit solutions including energy efficiency, fabric improvements, low carbon heating, building-level and local energy generation at scale. Such programmes would be led by local authorities and consortia based, including local community groups, retrofit providers, residents, energy suppliers and Local Enterprise Partnerships (LEPs).

Finally, future research in this area needs to explore the risk of summertime overheating of whole house retrofits in current and future climate projections. To ensure that such retrofits integrate climate mitigation and climate adaptation, the retrofit package is likely to include some kind of external shading over glazing, high albedo rendering of the exterior and reduction of urban heat island effect.

\section{Conclusion}

The study has demonstrated the application of a data driven localised novel domestic energy mapping approach that combined publicly-available top-down spatial datasets on energy, housing, socio-economics and fuel poverty with bottom-up DECoRuM energy modelling underpinned by actual dwelling details gathered through household questionnaire surveys conducted by the local low carbon community group. The approach was tested in a selected case study of 431 dwellings in Oxfordshire to create house-by-house baseline energy models and predict the potential for energy retrofits using ECO funded measures and whole house retrofit package. Multiple routes of identifying suitable dwellings for energy retrofits were tested such as grouping dwellings with high energy use, those with high levels of fuel 
poverty and by common dwelling characteristics. Four common dwelling typologies were identified in the case study area and these were assessed in more detail in terms of baseline and retrofit potential.

About 300 dwellings were found to be suitable for the whole house retrofit package, leading to an estimated $89-94 \%$ mean energy reduction in the local area. The most common dwelling typology, 1930s semi-detached, although had a high retrofit need but fell in area with low annual household income, suggesting the need for aligning existing funding sources (e.g. ECO) and leveraging private sector contributions. On the other hand, the second most common dwelling typology, 1930s terraced housing, were located in areas with median income level forming the 'able to pay' group. Funding programmes will need to be customised to meet the needs of these different segments of households, such as grants for low income households and interest-free loans for those with higher income, to increase the take-up of energy retrofits.

Following the shift of involvement and action to reduce emissions, from the central government to local government and community-based groups (Wade et al., 2013), local government and community groups need area-based tools to assess their local housing stock in order to improve it. The domestic energy mapping and analytics described in this study can improve the effectiveness and efficiency of delivering energy retrofit measures and related funding programmes to accelerate the transition to a low-carbon economy.

\section{Acknowledgement}

The authors would like to thank the Rose Hill and Iffley Low Carbon community group (RHILC), especially Eleanor Watts for her assistance with dwelling selection and community engagement. The study is undertaken as part of the European Regional Development Fund supported OxFutures initiative, a $£ 3.2 \mathrm{~m}$ project to boost low carbon economic development in Oxfordshire. The authors also acknowledge funding from the Innovate UK funded Project LEO (Project ref: 104781), EPSRC funded EnergyRev-Core project (EP/S031863/1) and EnergyRev Plus project on User influence tools (EP/S03188X/1).

\section{References}

Anderson, B. R., Chapman, P. F., Cutland, N. G., Dickson, C. M., Henderson, G., Henderson, J. H., Iles, P. J., Kosmina, L. \& Shorrock, L. D. (2002), "BREDEM-12 Model description: 2001 Update", Watford, Institute, B. R.

Architecture for London. (2018), Architects fees in the UK [Online]. London: Architecture for London. Available: https://architectureforlondon.com/news/architects-fees-in-the-uk/ [Accessed 2 September 2020].

Ariffin, S. T., Sulaiman, S., Mohammad, H., Yaman, S. K. \& Yunus, R. (2016), Factors of economies of scale for construction contractors. International Congress on Technology, Engineering, and Science (IConTES 2016). Vistana Hotel, Kuala Lumpur, Malaysia.

BEIS. (2016), Government emission conversion factors for greenhouse gas company reporting [Online]. London: Department for Business, Energy \& Industrial Strategy. Available: https://www.gov.uk/government/collections/government-conversion-factors-for-companyreporting\#conversion-factors-2016 [Accessed 2013].

BEIS. (2017), Sub-national consumption statistics [Online]. London: Department for Business, Energy \& Industrial Strategy. Available: https://www.gov.uk/government/publications/regional-energydata-guidance-note [Accessed 2018].

BEIS (2018), Clean Growth Strategy: Leading the way to a low carbon future. In: Department for Business, E. a. I. S. (ed.). London: HM Government.

BEIS (2019), Sub-national electricity consumption data. In: Department for Business, E. I. S. (ed.). London: UK Government.

BEIS \& Skidmore, C. (2019), UK becomes first major economy to pass net zero emissions law: New target will require the UK to bring all greenhouse gas emissions to net zero by 2050. [Online]. 
London: GOV.UK. Available: https://www.gov.uk/government/news/uk-becomes-first-majoreconomy-to-pass-net-zero-emissions-law [Accessed 30 Sep 2019].

BRE (2015), "BREDEM 2012: A technical description of the BRE domestic energy model: Version $1.1 "$.

Bruce-Konuah, A. \& Gupta, R. (2017), "Using smart energy storage to increase self-consumption of solar-generated electricity and reduce peak grid load at household and community level". ECEEE summer study proceedings, 2017. 1019-1029.

CACl (2020), Acorn: Understanding Consumers and Communities. In: $\mathrm{CACl}$ (ed.). London: CACl.

Calderón, C., James, P., Urquizo, J. \& McLoughlin, A. (2015), "A GIS domestic building framework to estimate energy end-use demand in UK sub-city areas", Energy and Buildings, Vol. 96 No., pp. 236-250.

Caputo, P. \& Pasetti, G. (2017), "Boosting the energy renovation rate of the private building stock in Italy: Policies and innovative GIS-based tools", Sustainable Cities and Society, Vol. 34 No., pp. 394-404.

CCC (2019), "UK housing: Fit for the future?", London, Change, C. o. C.

Centre for Sustainable Energy (2013), "Who's On Our Wires? Methodology Report: Low Carbon Technologies", Bristol, CSE.

Cityfied Project. (2015), Building solutions for boosting the energy retrofitting of buildings and districts in the cities of Valladolid and Malaga (Spain) [Online]. Available: http://www.cityfied.eu/News/Press-Releases/Finding-Solutions-For-Boosting-The-EnergyRetrofitting-Of-Buildings-And-Districts-In-The-Cities-Of-Valladolid-And-Malaga-Spain.kl [Accessed 2017].

Cluett, R. \& Amann, J. (2014), "Residential deep energy retrofits". 2014. American Council for an Energy Efficient Economy.

Cousins, A., Gitsham, M. \& Joss, A. (2010), Retrofit at scale: Refurbishing homes in Bristol [Online]. Available: https://www.forumforthefuture.org/retrofit-scale [Accessed 2018].

Crowley, R. \& GL, D. (2014), "'Watts" Where, and Why? Using GIS to Identify Energy Efficiency Opportunities", Vol. No., pp.

CSE. (2017), National heat map: New web-based tool to support low-carbon energy projects [Online]. Centre for Sustainable Energy. Available: https://www.cse.org.uk/projects/view/1183 [Accessed 29 March 2017 2017].

Currie \& Brown \& AECOM (2019), "The costs and benefits of tighter standards for new buildings", London, AECOM, C. B. a.

Davidson, M. (1995), "The English House Condition Survey: past, present and future", Structural Survey, Vol. 13 No. 4, pp. 28-29.

DCLG (2017), Energy Performance of Buildings Data: England and Wales. London: DCLG.

de Santoli, L., Mancini, F. \& Garcia, D. A. (2018), "A GIS-based model to assess electric energy consumptions and usable renewable energy potential in Lazio Region at municipality scale", Sustainable Cities and Society, Vol. No., pp.

Delmastro, C., Mutani, G. \& Schranz, L. (2016), "The evaluation of buildings energy consumption and the optimization of district heating networks: a GIS-based model", International Journal of Energy and Environmental Engineering, Vol. 7 No. 3, pp. 343-351.

Droutsa, K. G., Kontoyiannidis, S., Dascalaki, E. G. \& Balaras, C. A. (2016), "Mapping the energy performance of hellenic residential buildings from EPC (energy performance certificate) data", Energy, Vol. 98 No., pp. 284-295.

Early, C. (2020), Energy efficiency gap in buildings 'is undermining UK's bid to reach net-zero' [Online]. London: Ethical Corporation. Available: http://www.ethicalcorp.com/energyefficiency-gap-buildings-undermining-uks-bid-reach-net-zero [Accessed 25 May 2020].

Edina (2017), Historic Digimap. Edina.

Emden, J., Murphy, L. \& Lloyd, H. (2018), "Beyond ECO: The future of fuel poverty support", London, Research, T. I. f. P. P.

Energiesprong (2019), Energiesprong works! In: Energiesprong (ed.). energiesprong.org: Energiesprong.

Energy Systems Catapult (2019), "Homes fit for the Future; Retrofit towards a sector-wide roadmap 2020", London.

Energy Systems Catapult (2020), "Policy brief: Towards an enduring policy framework to decarbonize buildings".

Friedler, C. \& Kumar, C. (2019), "Reinventing retrofit: how to scale up home energy efficiency in the UK", London, Alliance, G. 
Gadsden, S., Rylatt, M., Lomas, K. \& Robinson, D. (2003), "Predicting the urban solar fraction: a methodology for energy advisers and planners based on GIS", Energy and Buildings, Vol. 35 No. 1, pp. 37-48.

Galante, A. \& Pasetti, G. (2012), "A methodology for evaluating the potential energy savings of retrofitting residential building stocks", Sustainable Cities and Society, Vol. 4 No., pp. 12-21.

Gaspari, J., Giglio, M. D., Antonini, E. \& Vodola, V. (2020), "A GIS-Based Methodology for Speedy Energy Efficiency Mapping: A Case Study in Bologna", Energies, Vol. 13 No. 9, pp. 2230.

Giffinger, Latzer, Kalasek, Ecker, Getzner, Janke, Böhm, Madner, Grob, Klima, Pont, Mahdavi, Schaffer, Plha, Eibl, Hager, Utri, Naveau, Holzkorn \& Berger (2014), "E_Profil: Quartiersprofile für optimierte energietechnische Transformationsprozesse".

Groppi, D., de Santoli, L., Cumo, F. \& Garcia, D. A. (2018), "A GIS-based model to assess buildings energy consumption and usable solar energy potential in urban areas", Sustainable cities and society, Vol. 40 No., pp. 546-558.

Gupta, R. (2009), "Moving towards low-carbon buildings and cities: experiences from Oxford, UK", International Journal of Low-Carbon Technologies, Vol. 4 No. 3, pp. 159-168.

Gupta, R., Bruce-Konuah, A. \& Howard, A. (2019), "Achieving energy resilience through smart storage of solar electricity at dwelling and community level", Energy and Buildings, Vol. 195 No., pp. 1-15.

Gupta, R. \& Gregg, M. (2013), "Preventing the overheating of English suburban homes in a warming climate", Building Research \& Information, Vol. 41 No. 3, pp. 281-300.

Gupta, R. \& Gregg, M. (2017), Local energy mapping using publicly available data for urban energy retrofit. Building Information Modelling, Building Performance, Design and Smart Construction. Springer.

Gupta, R. \& Gregg, M. (2018), Modeling and Mapping Domestic Energy Refurbishment Measures on a Community Scale. Urban Energy Transition. Elsevier.

Gupta, R., Gregg, M., Passmore, S. \& Stevens, G. (2015), "Intent and outcomes from the Retrofit for the Future programme: key lessons", Building Research \& Information, Vol. 43 No. 4, pp. 435-451.

Holmes, M. \& Stevenson, M. (2020), Should you demolish and replace? [Online]. Homebuilding \& Renovating. Available: https://www.homebuilding.co.uk/advice/demolish-and-replace [Accessed 2 September 2020].

IET (2018), "Scaling Up Retrofit 2050, in Why a nationwide programme to upgrade the existing housing stock is the only way for the UK to achieve its carbon saving goals".

Lannon, S., Georgakaki, A. \& Macdonald, S. (2013), "Modelling urban scale retrofit, pathways to 2050 low carbon residential building stock", Vol. No., pp.

Low Carbon Hub. (2020), People's Power Station [Online]. Available: https://peoplespowerstation.org/\#all::all::all::all::all::all::Energy\%20Efficiency,Renewable\%20E nergy [Accessed].

Mastrucci, A., Baume, O., Stazi, F. \& Leopold, U. (2014a), "Estimating energy savings for the residential building stock of an entire city: A GIS-based statistical downscaling approach applied to Rotterdam", Energy and Buildings, Vol. 75 No., pp. 358-367.

Mastrucci, A., Baume, O., Stazi, F., Salvucci, S. \& Leopold, U. (2014b), "A GIS-based approach to estimate energy savings and indoor thermal comfort for urban housing stock retrofitting", BauSIM 2014, Vol. No., pp. 190-197.

Mastrucci, A., Popovici, E., Marvuglia, A., De Sousa, L., Benetto, E. \& Leopold, U. (2015), "GIS-based Life Cycle Assessment of urban building stocks retrofitting-a bottom-up framework applied to Luxembourg". Envirolnfo and ICT for Sustainability 2015, 2015. Atlantis Press.

Mhalas, A., Crosbie, T. \& Dawood, N. (2012), "Development of A Visual Domestic Energy Assessment Tool". 12th International Conference on Construction Applications of Virtual Reality, 2012. National Taiwan University Press, 80-89.

MHCLG. (2017), Energy Performance of Buildings Data: England and Wales [Online]. London: Department For Communities and Local Government. Available: https://epc.opendatacommunities.org/ [Accessed 2019].

Moghadam, S. T., Mutani, G. \& Lombardi, P. (2016), "Gis-based energy consumption model at the urban scale for the building stock". 9th International Conference, Improving Energy Efficiency in Commercial Buildings \& Smart Communities Conference (IEECB \& SC'16), Frankfurt, 2016. 16-18.

NEF. (2020), SuperHomes [Online]. Milton Keynes: National Energy Foundation. [Accessed 02 March 2020]. 
Ofgem (2019a), Energy Company Obligation (ECO3) Guidance: Delivery Version 1.2. In: Ofgem (ed.). London: Ofgem.

Ofgem. (2019b), Overview of previous schemes [Online]. London: Ofgem. Available: https://www.ofgem.gov.uk/environmental-programmes/eco/overview-previous-schemes [Accessed 31 Jan 2019].

Ofgem. (2019c), Typical Domestic Consumption Values [Online]. Ofgem. Available: https://www.ofgem.gov.uk/gas/retail-market/monitoring-data-and-statistics/typical-domesticconsumption-values [Accessed 26 March 2019].

ONS (2016), 2011 Census data. In: Statistics, O. f. N. (ed.). London: Office for National Statistics.

Palmer, J. \& Cooper, I. (2013), United Kingdom housing energy fact file. In: DECC (ed.). London.

Palmer, J., Livingstone, M. \& Adams, A. (2017), "What does it cost to retrofit homes? Updating the Cost Assumptions for BEIS's Energy Efficiency Modelling", London.

Pedro, J., Silva, C. \& Pinheiro, M. D. (2018), "Scaling up LEED-ND sustainability assessment from the neighborhood towards the city scale with the support of GIS modeling: Lisbon case study", Sustainable Cities and Society, Vol. 41 No., pp. 929-939.

Pont, U., Latzer, D., Giffinger, R. \& Mahdavi, A. (2019), "Assessing Energy profiles of urban neighborhoods: A streamlined GIS-based approach". Applied Mechanics and Materials, 2019. Trans Tech Publ, 264-272.

Quan, S. J., Li, Q., Augenbroe, G., Brown, J. \& Yang, P. P.-J. (2015), Urban data and building energy modeling: A GIS-based urban building energy modeling system using the urban-EPC engine. Planning Support Systems and Smart Cities. Springer.

Ürge-Vorsatz, D. \& Herrero, S. T. (2012), "Building synergies between climate change mitigation and energy poverty alleviation", Energy policy, Vol. 49 No., pp. 83-90.

uSwitch. (2020), uSwitch [Online]. Available: https://www.uswitch.com/ [Accessed 2020].

Wade, J., Eyre, N., Parag, Y., Hamilton, J. \& Lindström, T. (2013), "Local energy governance: communities and energy efficiency policy", Proceedings: ECEEE 2013 Summer Study on Energy Efficiency, Vol. No., pp. 637-648.

Wyrwa, A. \& Chen, Y.-k. (2017), "Mapping urban heat demand with the use of GIS-based tools", Energies, Vol. 10 No. 5, pp. 720. 